\title{
A numerical study of convection in rainbands of Typhoon Morakot (2009) with extreme rainfall: roles of pressure perturbations with low-level wind maxima
}

\author{
C.-C. Wang ${ }^{1}$, H.-C. Kuo ${ }^{2}$, R. H. Johnson ${ }^{3}$, C.-Y. Lee ${ }^{2}$, S.-Y. Huang ${ }^{1}$, and Y.-H. Chen ${ }^{2}$ \\ ${ }^{1}$ Department of Earth Sciences, National Taiwan Normal University, Taipei, Taiwan \\ ${ }^{2}$ Department of Atmospheric Sciences, National Taiwan University, Taipei, Taiwan \\ ${ }^{3}$ Department of Atmospheric Sciences, Colorado State University, Fort Collins, CO, USA
}

Correspondence to: H.-C. Kuo (kuo@as.ntu.edu.tw)

Received: 19 December 2014 - Published in Atmos. Chem. Phys. Discuss.: 20 March 2015

Revised: 21 July 2015 - Accepted: 30 August 2015 - Published: 6 October 2015

\begin{abstract}
This paper investigates the formation and evolution of deep convection inside the east-west oriented rainbands associated with a low-level jet (LLJ) in Typhoon Morakot (2009). With the typhoon center to the northwest of Taiwan, the westerly LLJ occurred as a result from the interaction of typhoon circulation with the southwest monsoon flow, which supplied the water vapor for the extreme rainfall (of $\sim 1000 \mathrm{~mm}$ ) over southwestern Taiwan. The CloudResolving Storm Simulator with $1 \mathrm{~km}$ grid spacing was used to simulate the event, and it successfully reproduced the slow-moving rainbands, the embedded cells, and the dynamics of merger and back-building (BB) on 8 August as observed. Our model results suggest that the intense convection interacted strongly with the westerly LLJ that provided reversed vertical wind shear below and above the jet core. Inside mature cells, significant dynamical pressure perturbations $\left(p_{\mathrm{d}}^{\prime}\right)$ are induced with positive (negative) $p_{\mathrm{d}}^{\prime}$ at the western (eastern) flank of the updraft near the surface and a reversed pattern aloft $(>2 \mathrm{~km})$. This configuration produced an upward-directed pressure gradient force (PGF) to the rear side and favors new development to the west, which further leads to cell merging as the mature cells slowdown in eastward propagation. The strong updrafts also acted to elevate the jet and enhance the local vertical wind shear at the rear flank. Additional analysis reveals that the upward PGF there is resulted mainly by the shearing effect but also by the extension of upward acceleration at low levels. In the horizontal, the upstream-directed PGF induced by the rear-side positive $p_{\mathrm{d}}^{\prime}$ near the surface is much smaller, but can provide additional convergence for BB development upstream. Finally,
\end{abstract}

the cold-pool mechanism for BB appears to be not important in the Morakot case, as the conditions for strong evaporation in downdrafts do not exist.

\section{Introduction}

\subsection{Literature review}

Rainbands develop in response to linear forcing such as fronts, dry lines, troughs, and convergence zone (e.g., Carbone, 1982; Browning, 1990; Doswell III, 2001; Johnson and Mapes, 2001) or by self-organization in a sheared environment (e.g., Bluestein and Jain, 1985; Rotunno et al., 1988; Houze Jr. et al., 1990), and are a common type of precipitation systems around the world (e.g., Houze Jr., 1977; Chen and Chou, 1993; Garstang et al., 1994; LeMone et al., 1998; Meng et al., 2013). These linear-shaped mesoscale convective systems (MCSs) are most well studied in mid-latitudes and classified by Parker and Johnson $(2000,2004)$ into three archetypes based on the location of stratiform region relative to the main line: trailing stratiform (TS), leading stratiform (LS), and parallel stratiform (PS), in response primarily to the different structure of environmental vertical wind shear. Most of these quasi-linear MCSs, especially the TS archetype, are squall lines and propagate relatively fast in direction more-or-less normal to the line (Houze Jr. et al., 1990).

The above motion of squall-line type systems, however, is not particularly conducive to high rainfall accumulation 
and the occurrence of flash floods, as Schumacher and Johnson $(2005,2006)$ found that the three archetypes together constitute only about $30 \%$ of extreme precipitation events caused by MCSs over the Great Plains of the United States. For the more hazardous linear systems that travel at small angles to their own alignment (also Dowsell III et al., 1996; Brooks and Stensrud, 2000), the above authors further identified two common types of MCSs: the training line-adjoining stratiform (TL/AS) and back-building/quasi-stationary (BB), accounting for about 34 and $20 \%$ of the extreme rainfall events, respectively (Schumacher and Johnson, 2005, 2006). Inside the TL/AS type that often forms along or north of a pre-existing slow-moving boundary with an east-west (EW) orientation, a series of embedded "training" convective cells move eastward (also Stevenson and Schumacher, 2014; Peters and Roebber, 2014). On the other hand, the BB systems are more dependent on mesoscale and storm-scale processes than synoptic boundaries, and while the embedded cells move downwind after initiation, new cells are repeatedly generated at nearly the same location at the upwind side, making the line as a whole "quasi-stationary" (e.g., Chappell, 1986; Corfidi et al., 1996). Both the above configurations allow for multiple cells to pass through the same area successively, thus rainfall at high intensity to accumulate over a lengthy period (e.g., several hours) to cause extreme events and related hazards (Doswell III et al., 1996). The common mechanism of repeated new cell generation at the end of BB MCSs are through the lifting at the leading edge (i.e., gust front) of the outflow of storm-generated cold pool (see e.g., Fig. 7 of Doswell III et al., 1996), which forms on the upwind side of the system (e.g., Parker and Johnson, 2000; Schumacher and Johnson, 2005, 2009; Houston and Wilhelmson, 2007; Moore et al., 2012). Outside of North America, linear MCSs with embedded cells moving along the line are also often responsible for floods, such as the events in France, Australia, Hawaii, and eastern China (Sénési et al., 1996; Tryhorn et al., 2008; Murphy Jr. and Businger, 2011; Luo et al., 2014).

Another well-known theory through which the movement of convective cells, and thus the evolution of quasilinear MCSs, can be modified is the dynamical pressure change induced by the shearing effect in environments with strong vertical wind shear, first put forward by Rotunno and Klemp (1982) to explain the propagation of isolated supercell storms (also e.g., Weisman and Klemp, 1986; Klemp, 1987). The related diagnostics is also shown to be valid for convection in quasi-linear MCSs by Parker and Johnson (2004). To be detailed in Sect. 3.3, the convective-scale dynamical pressure perturbation $\left(p_{\mathrm{d}}^{\prime}\right)$ can be shown to be roughly proportional to the inner product of the vertical shear vector of horizontal wind $(\boldsymbol{S})$ and the horizontal gradient of vertical velocity $\left(\nabla_{\mathrm{h}} w\right)$. Thus, in an environment with westerly vertical shear ( $\boldsymbol{S}$ pointing eastward), positive (negative) $p_{\mathrm{d}}^{\prime}$ is induced to the west (east) of the updraft where $\nabla_{\mathrm{h}} w$ points eastward (westward, see e.g., Fig. 7a of Klemp, 1987). This produces
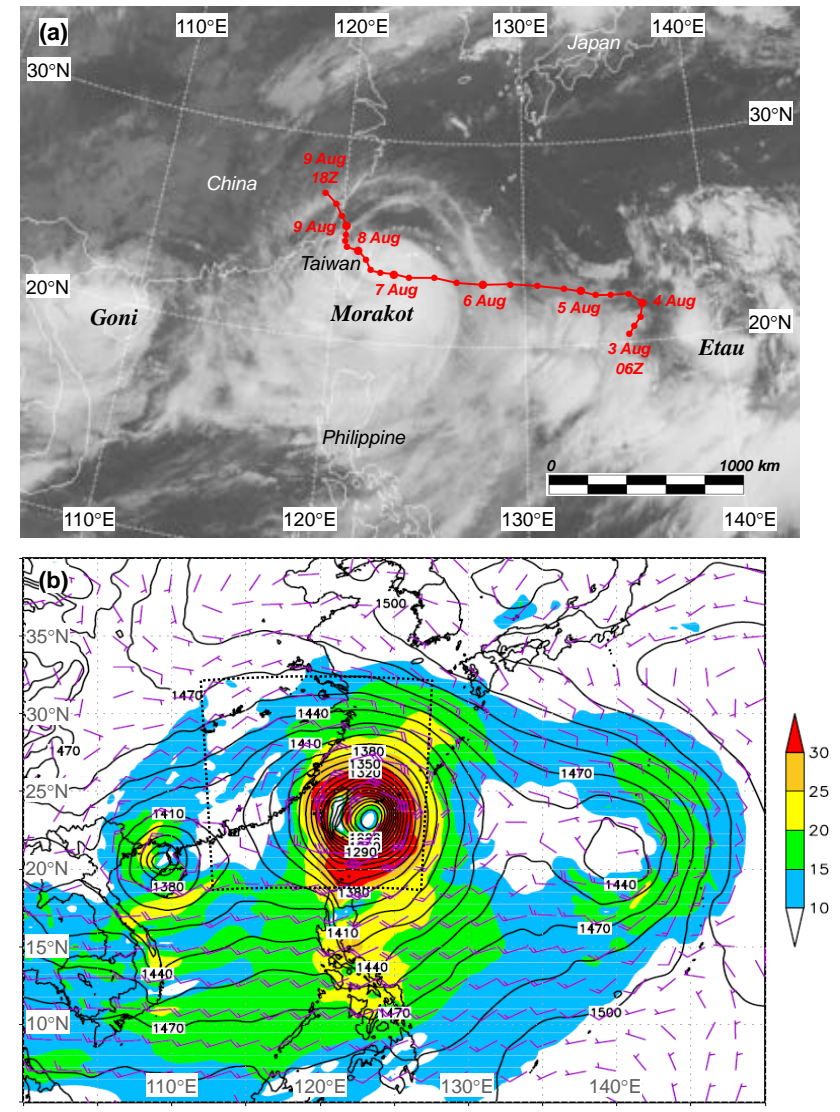

Figure 1. (a) The JTWC best-track of Typhoon Morakot (TY0908) overlaid with MTSAT IR cloud imagery at 00:30 UTC, 7 August 2009. The TC positions are given every $6 \mathrm{~h}$. (b) The ECMWFYOTC analysis of geopotential height (gpm, contours) and horizontal winds $\left(\mathrm{m} \mathrm{s}^{-1}\right.$, full (half) barb $=10(5) \mathrm{m} \mathrm{s}^{-1}$, wind speed shaded) at $850 \mathrm{hPa}$ at 00:00 UTC, 7 August 2009. The domain of $3 \mathrm{~km}$ experiment is also plotted (dotted region).

an eastward pressure gradient force (PGF) in the horizontal and favors new updraft development to the east (with $p_{\mathrm{d}}^{\prime}<0$ aloft), and helps the storm to propagate forward. In Wang et al. (2009), multiple supercell storms near Taiwan are successfully simulated without the use of initial warm bubbles, and the perturbation pressure $\left(p^{\prime}\right)$ couplets (rear-positive and front-negative with respect to $\boldsymbol{S}$ ) across the updraft are also reproduced. In the present study, the roles of pressure perturbations associated with convective cells inside the rainband of Typhoon (TY) Morakot in 2009 (e.g., Chien and Kuo, 2011; Wang et al., 2012) are investigated using the simulation results from a cloud-resolving model, and the background related to typhoon rainbands and this particular typhoon is introduced below.

\subsection{Typhoon Morakot and back-building rainbands}

Located over the western North Pacific (WNP), on average about 3-5 typhoons hit Taiwan annually and pose serious 
Table 1. Comparison of maximum accumulated rainfall (mm) observed in TY Morakot (2009) in Taiwan (Hsu et al., 2010) and the World's record rainfall, including location and date (source: World Meteorological Organization World Archive of Weather and Climate Extremes, available at http://wmo.asu.edu/\#global; Holland, 1993; Guhathakurta, 2007; Quetelard et al., 2009).

\begin{tabular}{rrrll}
\hline Duration & Morakot & \multicolumn{3}{c}{ World record } \\
\cline { 3 - 5 } & & Amount & Location & Date \\
\hline $24 \mathrm{~h}$ & 1624 & 1825 & Foc-Foc, La Réunion & 7-8 Jan 1966 \\
$48 \mathrm{~h}$ & 2361 & 2493 & Cherrapunji, India & 15-16 Jun 1995 \\
$72 \mathrm{~h}$ & 2748 & 3930 & Cratère Commerson, La Réunion & 24-26 Feb 2007 \\
$96 \mathrm{~h}$ & 2855 & 4936 & Cratère Commerson, La Réunion & 24-27 Feb 2007 \\
\hline
\end{tabular}
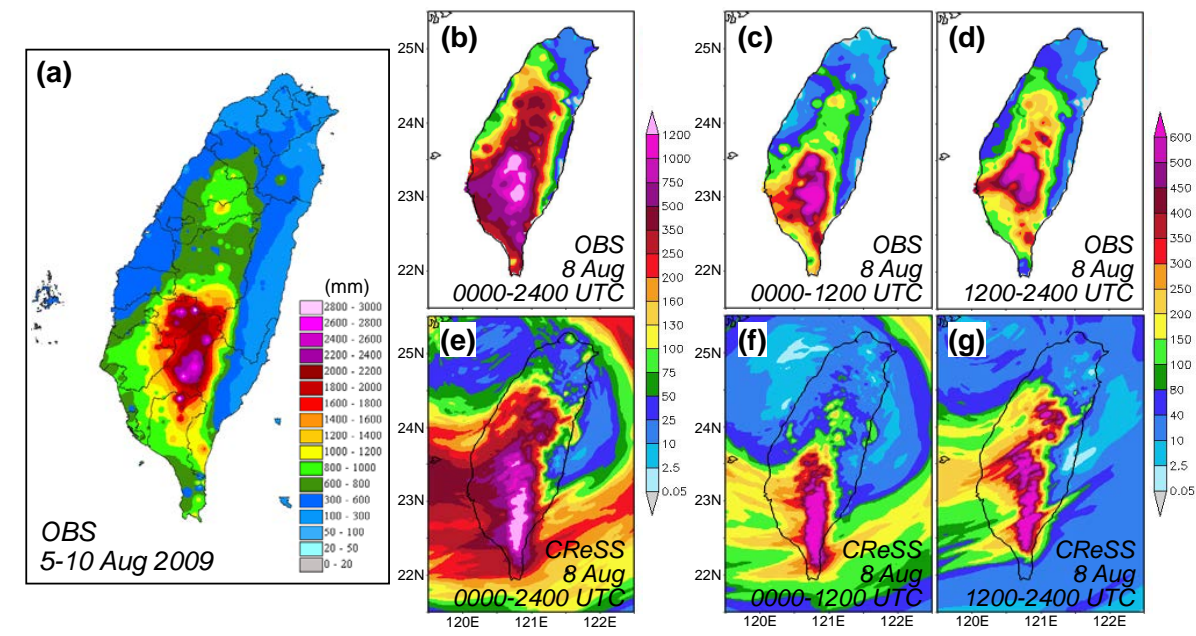

Figure 2. Observed (a) total rainfall distribution (mm) in Taiwan over 5-10 August, (b) daily (00:00-24:00 UTC) rainfall distribution on 8 August, and $12 \mathrm{~h}$ rainfall over (c) 00:00-12:00 UTC and (d) 12:00-24:00 UTC on 8 August, during Morakot (2009). (e-g) Same as (b-d) except from $1 \mathrm{~km}$ CReSS model simulation.

threats to the island. Some of them develop strong interaction with the monsoon that often further enhances the rainfall and worsens the damages. In the past 50 years, the most devastating case was TY Morakot in August 2009 (Lee et al., 2011; Chang et al., 2013), leading to 757 deaths and direct damages of roughly USD 3.8 billion (Wang et al., 2012). Based on the Joint Typhoon Warning Center (JTWC) best track, after its formation on 3 August, TY Morakot (2009) approached from the east since 4 August then impacted Taiwan during 6-9 August (Fig. 1a). Embedded inside a $4000 \mathrm{~km}$ monsoon gyre that enclosed two other tropical cyclones (TCs) (e.g., Hong et al., 2010; Nguyen and Chen, 2011), Morakot was large in size (Fig. 1a and b) and moved very slowly near Taiwan under the influence of its background environment (e.g., Chien and Kuo, 2011; Wu et al., 2011). During the departure period on 8 August, its mean translation speed further dropped to below $2 \mathrm{~m} \mathrm{~s}^{-1}$ for about $24 \mathrm{~h}$ (cf. Fig. 1a), attributed to the effects of asymmetrical latent heating that concentrated at the rear side of the storm over the southern and eastern quadrants (Wang et al., 2012, 2013a; Hsu et al., 2013). At only category 2 on the Saffir-Simpson scale, most of the Moarkot destruction was almost entirely from extreme rainfall (e.g., Hen- dricks et al., 2011) that reached $1624 \mathrm{~mm}$ in $24 \mathrm{~h}, 2361 \mathrm{~mm}$ in $48 \mathrm{~h}$, and $2748 \mathrm{~mm}$ in 72 (Fig. 2a and b; Hsu et al., 2010) and approached the world record (Table 1). While the above studies clearly indicate that the event of Morakot was resulted from interactions across a wide range of scales, the interplay between TC motion and convection was especially important since the heaviest rainfall over southern Taiwan took place on 8 August when the TC moved the slowest (Figs. 1a and 2a and b, Wang et al., 2012).

During 8 August, two types of rainbands appeared persistently over or near Taiwan to cause the extreme rainfall. One was aligned north-south (N-S) near $120.7^{\circ} \mathrm{E}$ along the windward slopes of the southern Central Mountain Range (Figs. 2a-d and 3a, Wang et al., 2012), produced through forced uplift of moisture-laden air by the steep topography at high precipitation efficiency (Yu and Cheng, 2013; Huang et al., 2014). On the other hand, the second type of rainbands was nearly E-W oriented and parallel to the flow. On 8 August when Morakot's center was over the northern Taiwan Strait, these E-W bands formed repeatedly over the southern Taiwan Strait, within the strong low-level convergence zone between the northerly to westerly TC circulation 

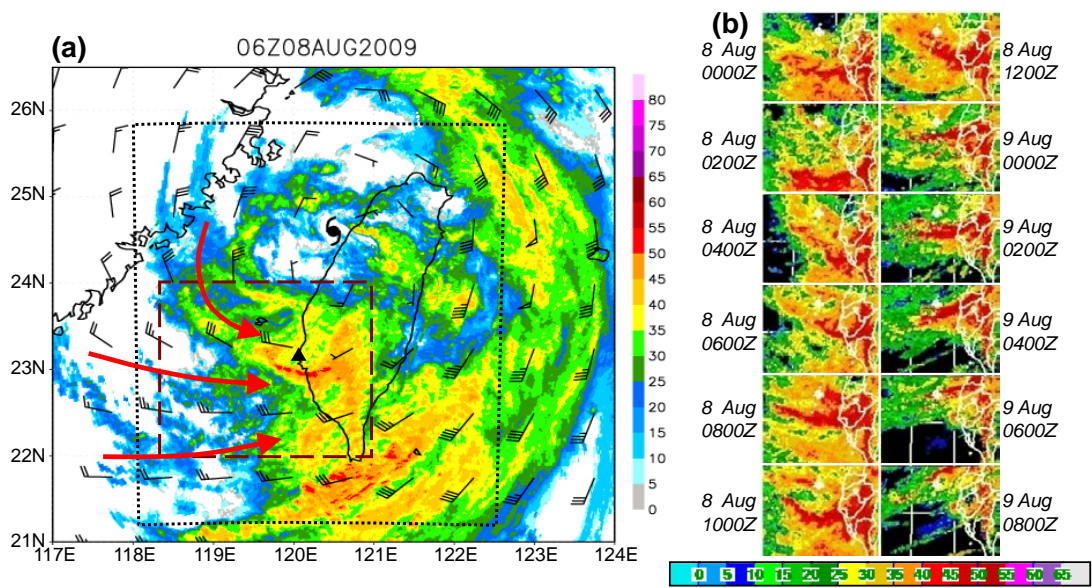

Figure 3. (a) The composite of radar VMI reflectivity (dBZ, scale on the right) near Taiwan overlaid with the ECMWF-YOTC 850 hPa horizontal winds $\left(\mathrm{ms}^{-1}\right.$, full (half) barb $=10(5) \mathrm{m} \mathrm{s}^{-1}$ ) at 06:00 UTC, 8 August 2009. The TC center is marked by the typhoon symbol, and the $1 \mathrm{~km}$ domain used in this study is also plotted (black dotted region). The triangle marks the location of Chigu radar. (b) Radar VMI reflectivity composites (dBZ, scale at bottom) over the brown dashed box in (a) every 2h over 00:00-12:00 UTC, 8 August and 00:0008:00 UTC, 9 August 2009.

and the monsoonal flow from the southwest, as illustrated in Fig. 3a at 06:00 UTC as an example. Together, the two rainbands formed a "T-shaped" pattern and persisted into 9 August as the TC gradually moved away (Fig. 3b). Similar combinations of topographic $(\mathrm{N}-\mathrm{S})$ and $\mathrm{TC} /$ monsoon (E-W) rainbands were also observed in several past TCs (Kuo et al., 2010), such as Mindulle (2004), Talim (2005), Haitang (2005), and Jangmi (2008), so it is not unique to Morakot. While some of them have also been noted for evident interaction with the southwesterly monsoon (Chien et al., 2008; Yang et al., 2008; Ying and Zhang, 2012), all are among the 12 most-rainy typhoons in Taiwan, while Morakot (2009) sits at the very top of the list (Chang et al., 2013).

The E-W rainbands can be classified as secondary bands (Fig. 3a), as apposed to the three other types of TC rainbands outside the eyewall: principle, connecting, and distant bands (Willoughby et al., 1984; Houze Jr., 2010). Within them, active and vigorous convective cells formed repeatedly off the coast of southwestern Taiwan and further upstream, then moved eastward over land, in a direction parallel to the band and the TC flow (Fig. 4, also Chen et al., 2010; Yu and Cheng, 2013). While several past studies have suggested that supercells may form in TC rainbands (e.g., Eastin and Link, 2009; Morin and Parker, 2011), the multi-cellular structure in Fig. 4 resembles those of both TL/AS and BB types of linear MCSs. An examination of hourly rainfall at gauges with a $24 \mathrm{~h}$ total $\geq 700 \mathrm{~mm}$ over the southwestern plains on 8 August reveals that at least $84 \%$ of the rain came from convective rainfall with an intensity $\geq 20 \mathrm{~mm} \mathrm{~h}^{-1}$, and the percentage was higher (up to $95 \%$ ) at sites with a higher amount $(>1000 \mathrm{~mm})$. Thus, the embedded convection were clearly responsible for the heavy rainfall and serious flooding

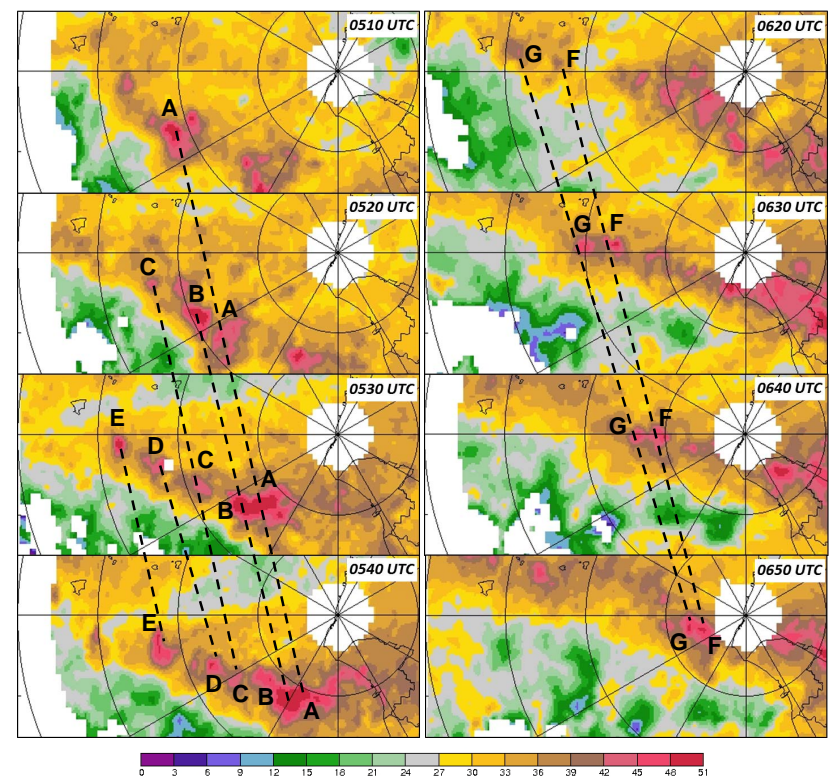

Figure 4. Series of CAPPI reflectivity (dBZ, scale at bottom) at $3 \mathrm{~km}$ observed by the Chigu radar (cf. Fig. 3 for location) every 10 min during 05:10-05:40 and 06:20-06:50 UTC, 8 August 2009, for regions of $100 \times 45 \mathrm{~km}^{2}$ covering the $\mathrm{E}-\mathrm{W}$ oriented rainbands (courtesy of C.-H. Liu). The concentric rings are $20 \mathrm{~km}$ apart. Selected back-building cells are labeled as A-G and cell motions are marked (dashed lines).

over much of the coastal plains in southwestern Taiwan (extending inland for about $50 \mathrm{~km}$, roughly west of $120.5^{\circ} \mathrm{E}$, cf. Figs. 2a-d and 3). In the examples shown in Fig. 4, backbuilding and merging and intensification of existing cells were both observed in the $\mathrm{E}-\mathrm{W}$ bands, and prior to their 

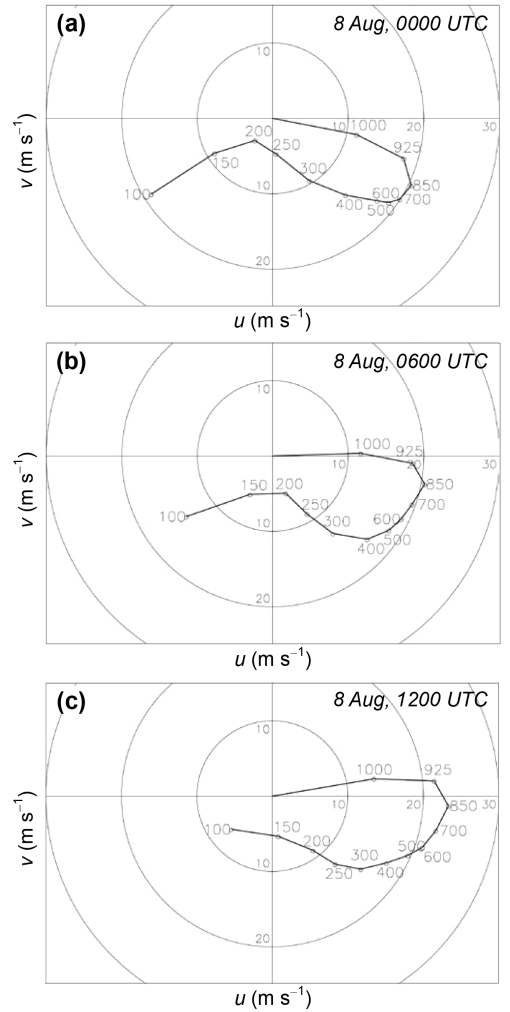

Figure 5. Hodograph of the mean wind $\left(\mathrm{m} \mathrm{s}^{-1}\right)$ inside 22 $24^{\circ} \mathrm{N}, 118.3-121^{\circ} \mathrm{E}$ (brown dashed box in Fig. 3a) computed from the ECMWF-YOTC analyses at (a) 00:00, (b) 06:00, and (c) 12:00 UTC, 8 August 2009. The numbers along the curve indicate pressure $(\mathrm{hPa})$ at nearby dots.

merger, the new cell to the west often moves faster than the old one. Such behaviors are known to be largely controlled by processes at convective scale. Therefore, besides a favorable forcing of low-level convergence between the TC circulation and southwesterly monsoon at meso- $\alpha$ and $\beta$ scale to trigger the convection and maintain the rainbands, whether processes at cloud and sub-cloud scale (meso- $\gamma$ ) also contributed in the detailed evolution of convection within the bands to cause the heavy rainfall over southwestern Taiwan? This is the focus of the present study.

In the typhoon environment, the maximum wind speed typically occurs near the top of the planetary boundary layer (PBL) due to thermal wind relationship and the influence of surface friction (e.g., Hawkins and Imbembo, 1976; Anthes, 1982, Sect. 2.3). Thus, the vertical wind shear is strongly cyclonic below the level of maximum wind and reverses in direction above it. At 00:00 UTC, 8 August, the areal-averaged environmental wind upstream and near southern Taiwan indeed exhibited a distinct west-northwesterly low-level jet (LLJ) reaching $20 \mathrm{~m} \mathrm{~s}^{-1}$ at $850 \mathrm{hPa}$, and the vertical shear below it reversed in direction at 700-200 $\mathrm{hPa}$ (Fig. 5a), reminiscent to the "hairpin" shape noted by Schumacher and Johnson (2009). At 06:00 and 12:00 UTC (Fig. 5b and c), the LLJ

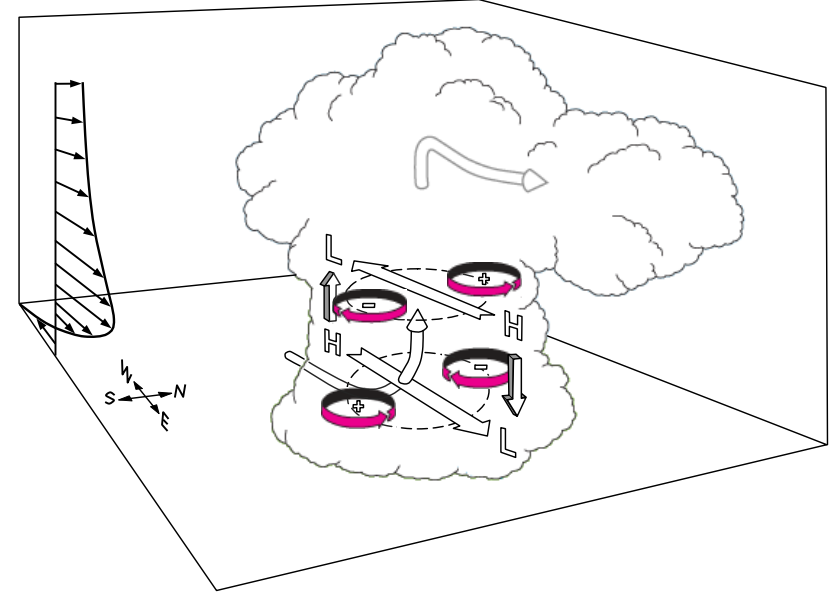

Figure 6. A schematic showing the distribution of dynamical pressure perturbations (marked by " $\mathrm{H}$ " for anomalous high and " $\mathrm{L}$ " for anomalous low) relative to a mature storm cell in an environment with the presence of a westerly low-level jet (LLJ) and westerly (easterly) vertical shear below (above) the jet core as in our case. The configuration is in favor of new development at the rear side and a slower moving speed of the cell.

and the associated shear through the deep troposphere turned slightly to the left (into more E-W directions), in response to the northwestward movement of Morakot (cf. Fig. 1a). While the LLJ was clearly a part of the TC circulation (e.g., Hence and Houze Jr., 2008), it was most likely enhanced by the southwesterly monsoon (cf. Fig. 3a). Based on Rotunno and Klemp (1982) and Klemp (1987), the interaction between convective updraft and its environmental flow (with LLJ and a reversed wind-shear in profile) would produce an anomalous high to the rear and an anomalous low ahead of the updraft near the surface (below the jet core) but a reversed pattern farther aloft (above the jet core). As illustrated by the schematic in Fig. 6, the effect from such dynamical pressure perturbations would be to favor updraft intensification to the west of mature cells and new development there, i.e., to the back side of the $\mathrm{E}-\mathrm{W}$ rainbands in our case. Thus, in the present study, we examine such a mechanism and the possible roles played by the pressure perturbations surrounding convective cells in storm evolution (such as back-building and cell merging) mainly through cloud-resolving numerical simulation. In the Morakot case, such meso- $\gamma$ scale processes and their potential roles in rainfall accumulation have not been studied previously.

\section{Data and methodology}

\subsection{Observational data}

The observational data used in this study include standard weather maps, the best-track data from the JTWC, infrared cloud imageries from the geostationary Multifunc- 

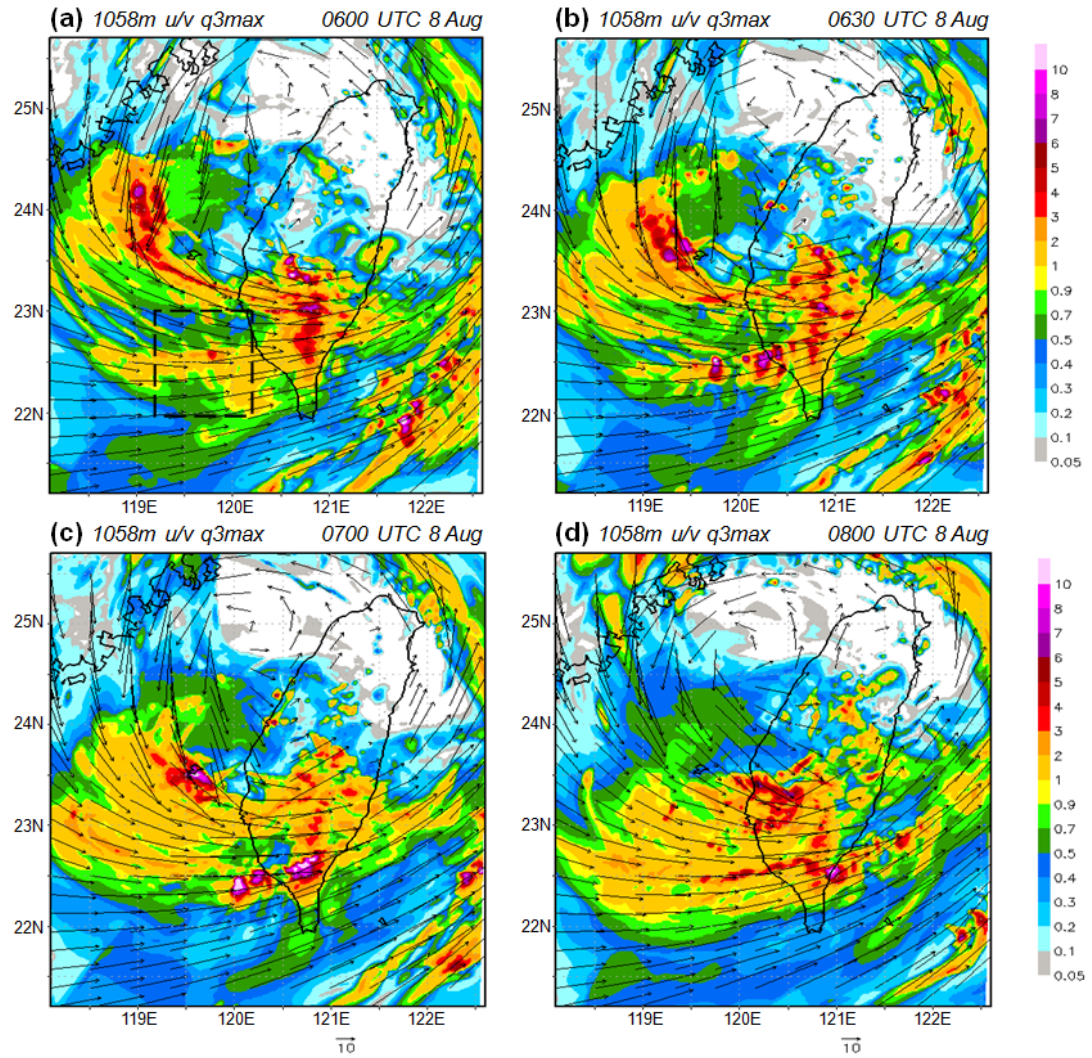

Figure 7. Model-simulated column maximum mixing ratio of total precipitating hydrometeors $\left(\mathrm{g} \mathrm{kg}^{-1}\right.$, rain + snow + graupel, colors, scales on the right) and horizontal winds $\left(\mathrm{m} \mathrm{s}^{-1}\right.$, reference vector at bottom) at 1058 $\mathrm{m}$ at (a) 06:00 UTC, (b) 06:30 UTC, (c) 07:00 UTC and (d) 08:00 UTC, 8 August 2009 in the $1 \mathrm{~km}$ run. The dashed box in (a) depicts the area of pressure perturbation calculation $\left(22-23^{\circ} \mathrm{N}\right.$, $\left.119.2-120.2^{\circ} \mathrm{E}\right)$.

tional Transport Satellite (MTSAT) of Japan, and data from the rain-gauge network (Hsu, 1998) and radars operated by the Central Weather Bureau (CWB) of Taiwan during our case period. The radar data also include the vertical maximum indicator (VMI) and constant-altitude point position indicator (CAPPI) of reflectivity. Many of the above data have been used in the figures discussed so far.

\subsection{Model and experiment}

In Wang et al. (2012), the evolution of TY Morakot on 8 August 2009 was simulated in close agreement with the observations using the Cloud-Resolving Storm Simulator (CReSS; Tsuboki and Sakakibara, 2007), with a horizontal grid spacing of $3 \mathrm{~km}$, a dimension of $480 \times 480 \times 50$ (vertically stretched grid with spacing $\Delta z=100-745 \mathrm{~m}$ ), and a model top of $25 \mathrm{~km}$. Using European Center for Mediumrange Weather Forecasts (ECMWF) Year of Tropical Convection (YOTC) analyses $\left(0.25^{\circ} \times 0.25^{\circ}\right.$ and 20 levels, every 6 h, e.g., Waliser and Moncrieff, 2007; Moncrieff, 2010) as the initial and boundary conditions (IC/BCs), this particular experiment (their R01 run) served as the control to compare with sensitivity tests designed to examine the effects of asymmetric latent heating on the slowing down of Morakot over the northern Taiwan Strait during its departure. Besides research, the model has also been used to perform real-time forecasts including those for TCs (Wang et al., 2013b; Wang, 2014, 2015).

For this study, a run similar to R01 was performed with identical setup, except that the model top is increased from 25 to $36 \mathrm{~km}$ with slightly reduced vertical resolution. This experiment is referred to as the $3 \mathrm{~km}$ run (Table 2) and provides the IC/BCs to a second experiment using a horizontal grid spacing of $1 \mathrm{~km}$ and 55 levels, such that detailed structure and evolution of the convective cells embedded inside the rainbands can be reproduced and studied. The integration length of the $1 \mathrm{~km}$ run is $24 \mathrm{~h}$ starting from 00:00 UTC, 8 August 2009, and model output intervals are $7.5 \mathrm{~min}$. The detailed domain configuration and physics of the $3 \mathrm{~km}$ and $1 \mathrm{~km}$ runs are shown in Table 2 (also cf. Figs. $1 \mathrm{~b}$ and $3 \mathrm{a}$ ). For later analysis and discussion, only outputs from the $1 \mathrm{~km}$ model are used. 
Table 2. Domain configuration, physics, and experiment design used in this study. In the vertical, the grid spacing $(\Delta z)$ of the CReSS model is stretched (smallest at the bottom), and the averaged spacing is given in the parentheses.

\begin{tabular}{|c|c|c|}
\hline & $3 \mathrm{~km}$ & $1 \mathrm{~km}$ \\
\hline Projection & \multicolumn{2}{|c|}{ Lambert Conformal, center at $120^{\circ} \mathrm{E}$, secant at 10 and $40^{\circ} \mathrm{N}$} \\
\hline Grid dimension $(x, y, z)$ & $480 \times 480 \times 50$ & $450 \times 500 \times 55$ \\
\hline Grid spacing $(\mathrm{km})$ & $3.0 \times 3.0 \times 0.1-0.98(0.72)$ & $1.0 \times 1.0 \times 0.1-0.718(0.5)$ \\
\hline Topography and SST & \multicolumn{2}{|c|}{ Real at $(1 / 120)^{\circ}$, and weekly mean at $1^{\circ}$ resolution } \\
\hline Initial/boundary conditions (IC/BCs) & $\begin{array}{l}\text { ECMWF YOTC analyses } \\
\left(0.25^{\circ} \times 0.25^{\circ}, 20 \text { levels, } 6 \mathrm{~h}\right)\end{array}$ & $\begin{array}{l}\text { Outputs from } 3 \mathrm{~km} \text { run }(3 \mathrm{~km}, 55 \text { levels, } \\
15 \mathrm{~min})\end{array}$ \\
\hline Initial time & \multicolumn{2}{|c|}{ 00:00 UTC, 8 Aug 2009} \\
\hline Integration length & $48 \mathrm{~h}$ & $24 \mathrm{~h}$ \\
\hline Output frequency & $15 \mathrm{~min}$ & $7.5 \mathrm{~min}$ \\
\hline Cloud microphysics & \multicolumn{2}{|c|}{ Bulk cold rain scheme (mixed phase with six species) } \\
\hline PBL parameterization & \multicolumn{2}{|c|}{ 1.5-order closure with TKE prediction } \\
\hline Surface processes & \multicolumn{2}{|c|}{ Energy/momentum fluxes, shortwave and longwave radiation } \\
\hline Soil model & \multicolumn{2}{|c|}{41 levels, every $5 \mathrm{~cm}$ to $2 \mathrm{~m}$ deep } \\
\hline
\end{tabular}

\subsection{Analysis of pressure perturbations}

In this study, to obtain the perturbation pressure $p^{\prime}$ associated with the convection in the $1 \mathrm{~km}$ model results for analysis, two different methods are employed. The first method is to define a background field that varies both with space and time, then separate $p^{\prime}$ by subtracting the background from the total field. In our case, since the TC center is located to the north and gradually moving away from the analysis area, set to $22-23^{\circ} \mathrm{N}, 119.2-120.2^{\circ} \mathrm{E}\left(1^{\circ} \times 1^{\circ}\right.$, cf. Fig. $\left.7 \mathrm{a}\right)$, the accompanying changes, including those with time, need to be partitioned into the background field. For pressure $p(x, y, z, t)$, its spatial mean over a fixed area is $\bar{p}_{\mathrm{A}}(z, t)$ and its time average over a period from $t_{1}$ to $t_{2}$ is $\bar{p}_{t}(x, y, z)$. The time average of the spatial mean of $p$ is thus $\bar{p}_{\mathrm{A} t}(z)$, which varies only with $z$. Here, we define $\Delta p$ as the deviation of $\bar{p}_{\mathrm{A}}(z, t)$ from its time average $\bar{p}_{\mathrm{A} t}(z)$ as

$\Delta p(z, t)=\bar{p}_{\mathrm{A}}(z, t)-\bar{p}_{\mathrm{A} t}(z)$.

Thus, $\Delta p$ can account for the gradual increase of the arealmean pressure with time as the TC moves northward. Containing the averaged spatial pattern plus the change in its mean value with time, the background pressure $\left(p_{0}\right)$ is defined and computed as

$p_{0}(x, y, z, t)=\bar{p}_{t}(x, y, z)+\Delta p(z, t)$,

and $p^{\prime}$ is obtained subsequently as

$p^{\prime}(x, y, z, t)=p(x, y, z, t)-p_{0}(x, y, z, t)$.

Thus, the background pressure $p_{0}$ is not a function of $z$ only, but also varies with location and time. Here, the time period for analysis is selected to be 03:00-12:00 UTC, 8 August. When needed, the above method is also applied to other variables to obtain their perturbations, including horizontal wind $(u, v)$ and virtual potential temperature $\left(\theta_{v}\right)$.

To further examine the detailed roles of pressure perturbation on the development and evolution of convection, the vertical momentum equation is analyzed and the two components of $p^{\prime}$, the dynamical $\left(p_{\mathrm{d}}^{\prime}\right)$ and buoyancy $\left(p_{\mathrm{b}}^{\prime}\right)$ pressure perturbations (thus $p^{\prime}=p_{\mathrm{d}}^{\prime}+p_{\mathrm{b}}^{\prime}$ ), are evaluated following Rotunno and Klemp (1982), Klemp (1987), and Parker and Johnson (2004). In this second method, $p_{\mathrm{d}}^{\prime}$ and $p_{\mathrm{b}}^{\prime}$ and any of their contributing terms can be solved numerically through the relaxation method by iteration. For better clarity, the relevant formulation and procedure will be described later in Sect. 3.2 and 3.3, immediately followed by the results obtained from the $1 \mathrm{~km}$ simulation for selected convective cells with the presence of a westerly wind speed maximum near the top of the PBL in the Morakot case.

\section{Results of model simulation}

\subsection{Model result validation}

The CReSS model-simulated column maximum mixing ratio of total precipitating hydrometeors (rain + snow + graupel) in the $1 \mathrm{~km}$ run over the period of 06:00-08:00 UTC, $8 \mathrm{Au}-$ gust 2009 is shown in Fig. 7, which can be compared with the radar reflectivity composites in Fig. 3 and Wang et al. (2012, their Figs. 6e-g and 7). Comparison of these figures suggests that the model successfully reproduces the rainbands 
associated with TY Morakot near southwestern Taiwan over this period. On many occasions, more than one roughly E-W aligned bands (as observed) are simulated along a relatively wide zone of low-level convergence between the northerly to westerly TC flow and the west-southwesterly monsoon flow (Fig. 7). These modeled rainbands are in general agreement with earlier observational studies using radars (e.g., Chen et al., 2010; Yu and Cheng, 2013; Wei et al., 2014) while there are often slight displacements in their exact locations, typically by no more than $50 \mathrm{~km}$. Nevertheless, the simulated accumulated rainfall distribution (Fig. 2e-g) compares favorably with the gauge observations on 8 August, including both 00:00-12:00 and 12:00-24:00 UTC (cf. Fig. 2b-d).

In the model, convective cells embedded inside the rainbands are repeatedly generated and move eastward after initiation, as in the observation (cf. Fig. 4), and the phenomena of back-building and cell mergers are successfully captured. For example, Fig. 8 shows the development and evolution of several convective cells near $22.5^{\circ} \mathrm{N}$ using model outputs at $1058 \mathrm{~m}$ every $7.5 \mathrm{~min}$ over 06:30-07:00 UTC. Already mature at the beginning of this $30 \mathrm{~min}$ period, cell "A1" moves eastward at an estimated speed of $26.1 \mathrm{~m} \mathrm{~s}^{-1}$, while cells "B1" and " $\mathrm{C} 1$ " also travel slightly faster at their mature stage. Meanwhile, new cells, labeled as "A2", "B2", and "C2", respectively, are initiated just upstream (to the west) of each of the three mature cells (Fig. 8), corresponding to back-building behavior as observed (cf. Fig. 4). At the early development stage, the new cells also tend to travel faster than the adjacent old cells, most evidently for A2 that reached $31.1 \mathrm{~m} \mathrm{~s}^{-1}$ and eventually catches up and merges with cell A1 shortly after 07:00 UTC. Thus, the merging behavior of convective cells is also reproduced and linked to the slowingdown of mature cells, with a cycle of roughly $30-40 \mathrm{~min}$ in agreement with the observation (cf. Fig. 4). Although Figs. 4 and 8 only show a few selected cells as examples, similar back-building and merging behaviors are quite common both in observations and the $1 \mathrm{~km}$ run throughout 8 August (detailed figures not shown).

Since cells A1 and A2 exhibit typical evolution in the model with clear merging and back-building behavior, this particular pair of mature, new cells is selected for detailed study. Figure 9 presents the model-simulated horizontal winds and convergence/divergence associated with cell $\mathrm{A} 1$ at 547 and $2013 \mathrm{~m}$ at 06:30 UTC. While the rainband develops within the low-level convergence zone and the background westerly flow (i.e., the LLJ) increased in speed toward the east (about $35 \mathrm{~m} \mathrm{~s}^{-1}$ at $1058 \mathrm{~m}$ near A1; cf. Fig. 7b), the airflow surrounding the mature cell is very different, indicating significant local modulation on the jet by deep convection. Near the surface (Fig. 9a), a wind speed maximum-minimum couplet exists across the updraft (higher wind speed upstream) with a west-southwest-east-northeast (WSW-ENE) orientation and strong deceleration and convergence. At $547 \mathrm{~m}$, the pattern of convergence closely resembles that of vertical motion at $1058 \mathrm{~m}$ (cf. Fig. 8, top panel) and extends

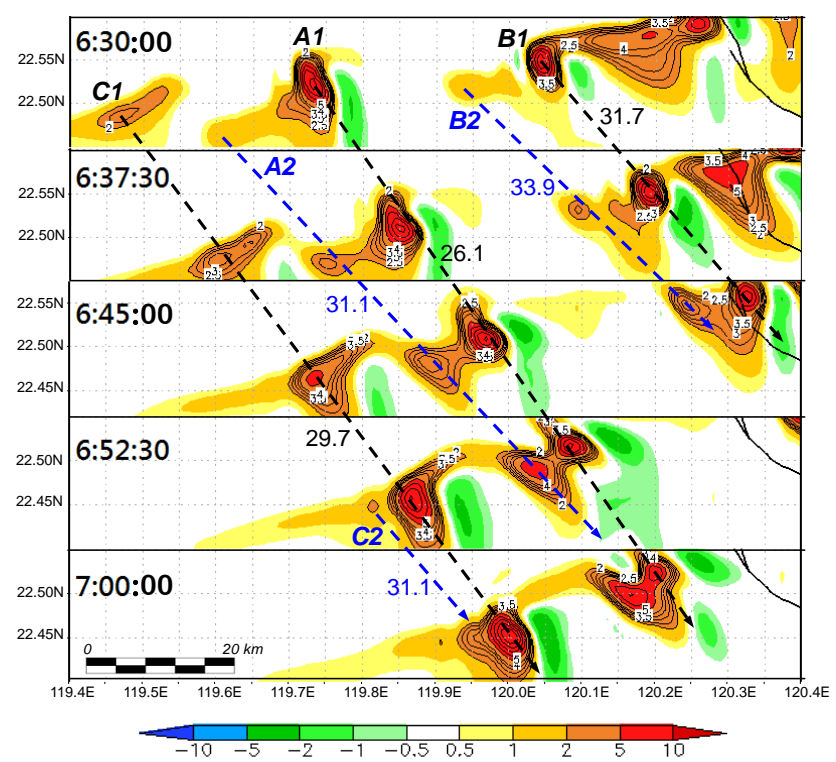

Figure 8. Similar to Fig. 4, but showing model-simulated vertical velocity ( $\mathrm{m} \mathrm{s}^{-1}$, color shades and contours) at the height of $1058 \mathrm{~m}$ (sixth output level) over the period of 06:30-07:00 UTC (every $7.5 \mathrm{~min}) 8$ August 2009 from the $1 \mathrm{~km}$ experiment. Contours start from $2 \mathrm{~m} \mathrm{~s}^{-1}$, at intervals of $0.5(1.0) \mathrm{m} \mathrm{s}^{-1}$ up to (above) $4 \mathrm{~m} \mathrm{~s}^{-1}$. Old cells (A1, B1, and C1) and nearby new cells (A2, B2, and C2) and their estimated propagation speeds $\left(\mathrm{m} \mathrm{s}^{-1}\right)$ are labeled.

south and west toward the area of new cell initiation (of A2), mainly due to the deceleration in $u$ wind and confluence in $v$ wind, respectively. From 39 to $22 \mathrm{~m} \mathrm{~s}^{-1}$, the speed convergence in $u$ across $\mathrm{A} 1$ at this level is about $5 \times 10^{-3} \mathrm{~s}^{-1}$ and twice the magnitude of the confluence in $v$, consistent with the deep convection (Fig. 9a). On the other hand, the divergence at $547 \mathrm{~m}$ is generally located east and southeast (SE) of the updraft. At $2013 \mathrm{~m}$ (Fig. 9b), the updraft core appears slightly to the east and thus is tilted downstream, while the wind speed couplet turns slightly to a SW-NE alignment with similar convergence (from $\sim 45$ to $29 \mathrm{~m} \mathrm{~s}^{-1}$ ).

In the $\mathrm{E}-\mathrm{W}$ vertical cross-section along $22.5^{\circ} \mathrm{N}$, which slices through (or near) several cells including $\mathrm{C} 1, \mathrm{~A} 1$, and B1 at 06:30 UTC (near 119.5, 119.75, and $120.05^{\circ} \mathrm{E}$, respectively, cf. Figs. 7b and 8), the local deceleration of westerly winds and convergence across convective cells at low levels are evident, while the oncoming environmental flow clearly has the structure of a LLJ with increased speed downstream and a core near $1 \mathrm{~km}$ in altitude (Fig. 10a). Away from the jet core level, the wind speed decreases much more rapidly below than above, suggesting strong westerly vertical wind shear near the surface $\left(>10^{-2} \mathrm{~s}^{-1}\right.$ in vorticity) but weak easterly shear above the LLJ, in agreement with Fig. 5. Across the $u$ wind couplets, the maximum speed typically occurs near $2 \mathrm{~km}$, indicating an upward transport of momentum of the jet by the updraft, and the minimum speed is toward the surface. Another cross-section (about $2 \mathrm{~km}$ north) that cuts 

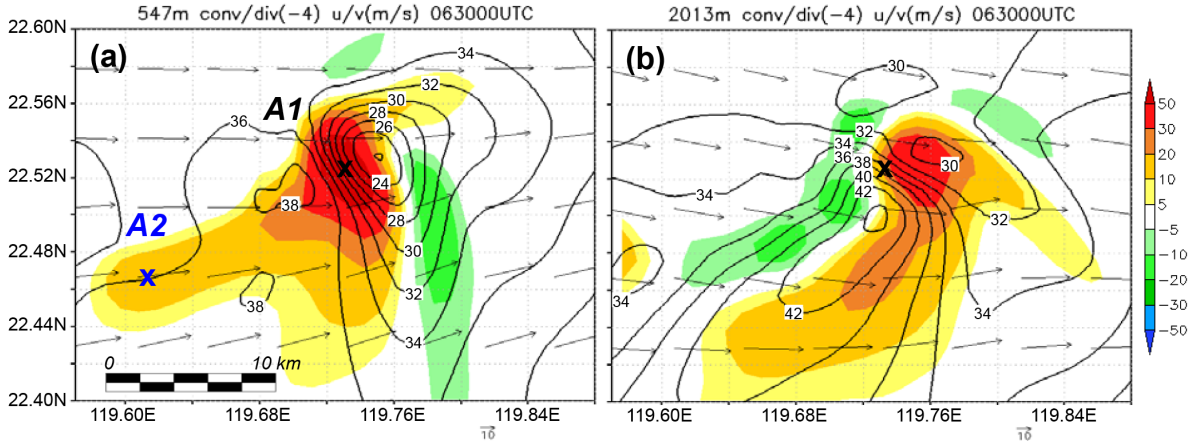

Figure 9. Model-simulated horizontal winds $\left(\mathrm{m} \mathrm{s}^{-1}\right.$, vectors, reference vector at bottom), wind speed (contours, intervals: $\left.2 \mathrm{~m} \mathrm{~s}^{-1}\right)$, and convergence/divergence $\left(10^{-4} \mathrm{~s}^{-1}\right.$, color, positive for convergence, scales on the right) at (a) $547 \mathrm{~m}$ (fourth output level) and (b) $2013 \mathrm{~m}$ (ninth output level) associated with the convective cell "A1" off the southwestern coast of Taiwan at 06:30 UTC, 8 August 2009. The "x" marks the updraft center at $1058 \mathrm{~m}$ (cf. Fig. 8).

through the center of A1 (cf. Fig. 8) is shown in Fig. 10b and provides a close-up view of this mature cell, of which the updraft indeed tilts eastward (downwind) with height (also Wei et al., 2014). Inside the updraft, air parcels accelerate upward to reach near $20 \mathrm{~m} \mathrm{~s}^{-1}$ at mid-levels, and this clearly contributes to the strong low-level convergence, and thus the wind speed couplet, through continuity. Due to the eastward tilt of the updraft, maximum precipitation and nearsurface downdraft (below $2 \mathrm{~km}$ ) both occur slightly downwind (Fig. 10b; cf. Fig. 8). This is also depicted in Fig. 11, which in addition confirms only small surface temperature variations, within $0.5 \mathrm{~K}$, over the rainfall area (centered near $119.77^{\circ} \mathrm{E}$ ). Thus, the cold pool is very weak (cf. Yu and Chen, 2011) and the induced outflow cannot reach the vicinity of A2 (Fig. 11). These figures suggests that locally, the evaporative cooling in the downdraft (reflected by a downward decrease in hydrometeors) is barely enough to overcome the adiabatic warming effect, since the near-surface air is very moist (close to saturation) and a mid-level drier layer is also lacking in typhoon environment. Thus, the cold-pool mechanism commonly seen in mid-latitudes to initiate new cells (Doswell III et al., 1996) does not seem important in our case here. Nevertheless, from Figs. 8-10, we see that the model cells, especially the mature ones, are moving at speeds slower than their low-level background flow, and we focus on the possible roles played by the pressure perturbations at subcloud scale in merging and back-building behaviors. Below, the vertical momentum equation is analyzed.

\subsection{Analysis of vertical momentum equation}

Following Rotunno and Klemp (1982) and Klemp (1987), the three-dimensional momentum equation can be expressed as

$\frac{\mathrm{d} \boldsymbol{v}}{\mathrm{d} t}+\frac{1}{\rho} \nabla p=-g \hat{\boldsymbol{k}}-f \hat{\boldsymbol{k}} \times \boldsymbol{v}+\boldsymbol{F}^{*}$, where $\boldsymbol{v}(u, v, w)$ is the velocity vector, $\rho$ is air density, $g$ is gravitational acceleration, $f$ is the Coriolis parameter, $\hat{\boldsymbol{k}}$ the unit vector in $z$ direction, and $\boldsymbol{F}^{*}\left(F_{x}^{*}, F_{y}^{*}, F_{z}^{*}\right)$ the frictional term. Both $p$ and $\rho$ can be separated into the background and perturbation (i.e., $p=p_{0}+p^{\prime}$ and $\rho=\rho_{0}+\rho^{\prime}$, note that $p_{0}$ here is not the same as the one given in Eq. 2) and the former is assumed to be in geostrophic and hydrostatic equilibrium. At convective scale, the Coriolis force is neglected and friction is replaced by a turbulent mixing term $\boldsymbol{F}\left(F_{x}, F_{y}, F_{z}\right)$. Thus, the horizontal acceleration is caused by the perturbation PGF and turbulent mixing as

$\frac{\mathrm{d} v_{\mathrm{h}}}{\mathrm{d} t}=-\frac{1}{\rho} \nabla_{\mathrm{h}} p^{\prime}+F_{x}+F_{y}$,

where the subscript $\mathrm{h}$ denotes the horizontal components, while the vertical acceleration $(\mathrm{d} w / \mathrm{d} t)$ can be approximated as

$$
\begin{aligned}
\frac{\mathrm{d} w}{\mathrm{~d} t} & =-\frac{1}{\rho} \frac{\partial p^{\prime}}{\partial z}-\frac{\rho^{\prime}}{\rho} g+F_{z} \approx-\frac{1}{\rho_{0}} \frac{\partial p^{\prime}}{\partial z}-\frac{\rho^{\prime}}{\rho_{0}} g+F_{z} \\
& =-\frac{1}{\rho_{0}} \frac{\partial p^{\prime}}{\partial z}+B+F_{z},
\end{aligned}
$$

where $B=-g\left(\rho^{\prime} / \rho_{0}\right)$ is the buoyancy acceleration. Thus, the vertical acceleration is driven by an imbalance among the perturbation PGF, buoyancy, and turbulent mixing.

The buoyancy $B$ is composed of effects from gaseous phase and condensates; the former can be accounted for by the virtual potential temperature perturbation $\left(\theta_{v}^{\prime}\right.$, where $\left.\theta_{v}=\theta_{v 0}+\theta_{v}^{\prime}\right)$. and the latter is the drag by cloud particles and precipitation, such that

$B=-\frac{\rho^{\prime}}{\rho_{0}} g=g \frac{\theta_{v}^{\prime}}{\theta_{v 0}}-g\left(q_{\mathrm{c}}+q_{\mathrm{i}}+q_{\mathrm{r}}+q_{\mathrm{s}}+q_{\mathrm{g}}\right)$,

where $q_{\mathrm{c}}, q_{\mathrm{i}}, q_{\mathrm{r}}, q_{\mathrm{s}}$, and $q_{\mathrm{g}}$ are mixing ratios of cloud water, cloud ice, rain, snow, and graupel, respectively, and available from model outputs. The separation of $\theta_{v 0}$ and $\theta_{v}^{\prime}$ is performed using the same method described in Sect. 2.3. Using 

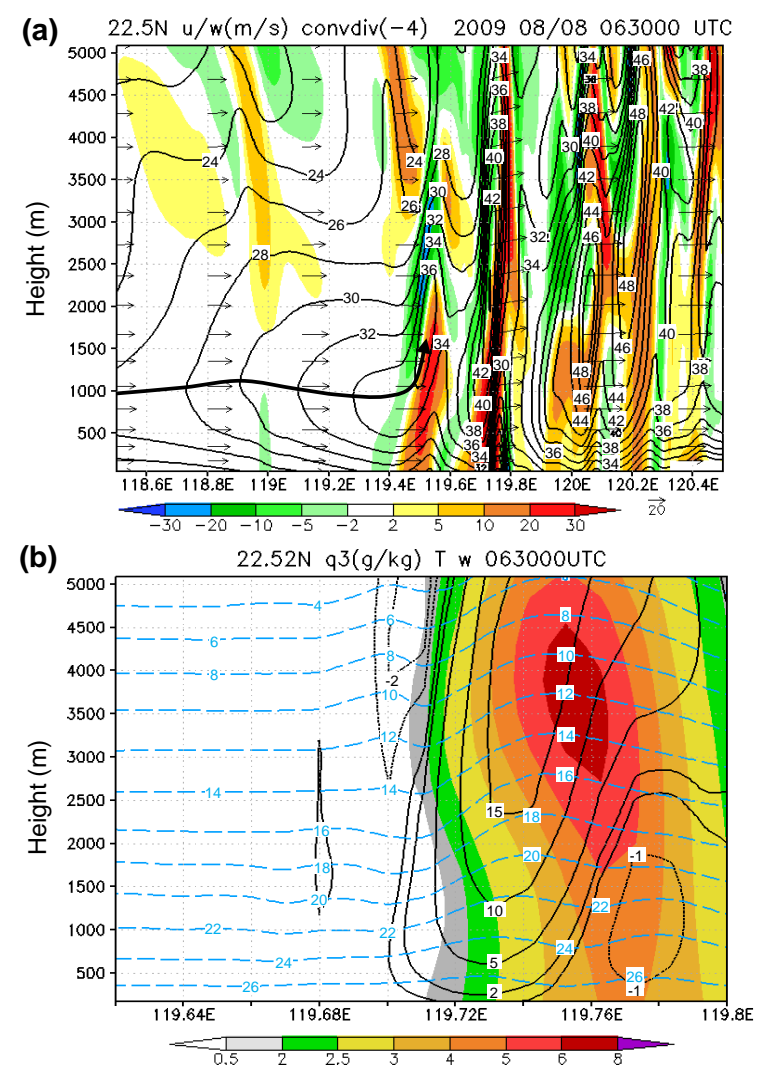

Figure 10. E-W vertical cross sections, through cell A1, of modelsimulated (a) wind vectors on the section plane $\left(\mathrm{m} \mathrm{s}^{-1}\right.$, reference vector at bottom), and horizontal wind speed $\left(\mathrm{m} \mathrm{s}^{-1}\right.$, isotachs, every $\left.2 \mathrm{~m} \mathrm{~s}^{-1}\right)$ and convergence/divergence $\left(10^{-4} \mathrm{~s}^{-1}\right.$, color, scale at bottom, positive for convergence) along $22.5^{\circ} \mathrm{N}$ from 118.5 to $120.5^{\circ} \mathrm{E}$ (about $200 \mathrm{~km}$ in length), and (b) vertical velocity $\left(\mathrm{m} \mathrm{s}^{-1}\right.$, contours, at $\pm 1, \pm 2, \pm 5, \pm 10$, and $\pm 15 \mathrm{~m} \mathrm{~s}^{-1}$, dotted for downward motion), temperature $\left({ }^{\circ} \mathrm{C}\right.$, dashed cyan isotherms, every $\left.2{ }^{\circ} \mathrm{C}\right)$, and mixing ratio of total precipitation $\left(\mathrm{g} \mathrm{kg}^{-1}\right.$, color, scale at bottom), along $22.52^{\circ} \mathrm{N}$ from 119.62 to $119.8^{\circ} \mathrm{E}$ (about $18 \mathrm{~km}$ in length) at 06:30 UTC, 8 August 2009. The thick arrow-line in (a) marks the axis of LLJ in the background flow.

$p^{\prime}=p_{\mathrm{d}}^{\prime}+p_{\mathrm{b}}^{\prime}$, Eq. (6) can be rewritten to divide the perturbation PGF into two separate terms as

$$
\begin{aligned}
\frac{\mathrm{d} w}{\mathrm{~d} t} & =\frac{\partial w}{\partial t}+u \frac{\partial w}{\partial x}+v \frac{\partial w}{\partial y}+w \frac{\partial w}{\partial z} \\
& =-\frac{1}{\rho_{0}} \frac{\partial p_{\mathrm{d}}^{\prime}}{\partial z}-\left(\frac{1}{\rho_{0}} \frac{\partial p_{\mathrm{b}}^{\prime}}{\partial z}-B\right)+F_{z}
\end{aligned}
$$

Here, the equation of total derivative is used, and the vertical acceleration is driven by the dynamical perturbation PGF, the buoyancy effect (which contains both the buoyancy perturbation PGF and buoyancy acceleration), and turbulent mixing.

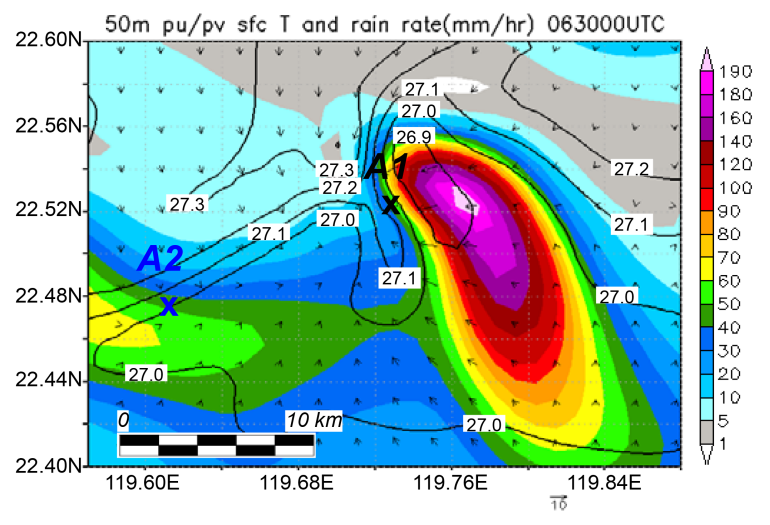

Figure 11. As in Fig. 9a, but showing model-simulated surface air temperature $\left({ }^{\circ} \mathrm{C}\right.$, contours, intervals: $\left.0.1{ }^{\circ} \mathrm{C}\right)$, horizontal wind perturbation $\left(u^{\prime}, v^{\prime}\right)$ at $50 \mathrm{~m}\left(\mathrm{~m} \mathrm{~s}^{-1}\right.$, vectors, reference vector at bottom), and (instantaneous) rain rate $\left(\mathrm{mm} \mathrm{h}^{-1}\right.$, color, scales on the right) at 06:30 UTC, 8 August 2009. The " $x$ " marks the updraft/ascending centers of A1 and A2 at $50 \mathrm{~m}$.

\subsection{Analysis of dynamical and buoyancy pressure perturbations}

Through the use of nearly incompressible Poisson equation, Rotunno and Klemp (1982) and Klemp (1987) can obtain $p_{\mathrm{d}}^{\prime}$ and $p_{\mathrm{b}}^{\prime}$ as the following. First, Eqs. (5) and (6) in Sect. 3.2 can be combined as

$\frac{\partial \boldsymbol{v}}{\partial t}+\boldsymbol{v} \cdot \nabla \boldsymbol{v}+\frac{1}{\rho_{0}} \nabla p^{\prime}=B \hat{\boldsymbol{k}}+\boldsymbol{F}$,

and the anelastic continuity equation is

$\nabla \cdot \rho_{0} \boldsymbol{v}=0$.

When Eq. (9) is multiplied through by $\rho_{0}$ then applied the three-dimensional gradient operator, the first left-hand-side term vanishes using Eq. (10), and the dynamical and buoyancy terms can be separated as

$\begin{aligned} \nabla^{2} p_{\mathrm{b}}^{\prime} & =\frac{\partial}{\partial z}\left(\rho_{0} B\right) \text { and } \\ \nabla^{2} p_{\mathrm{d}}^{\prime} & =-\nabla \cdot\left(\rho_{0} \boldsymbol{v} \cdot \nabla \boldsymbol{v}\right)+\nabla \cdot\left(\rho_{0} \boldsymbol{F}\right)\end{aligned}$

After expansion and cancellation of terms with friction omitted, Eq. (12) can be rewritten as

$$
\begin{aligned}
& \nabla^{2} p_{\mathrm{d}}^{\prime}=-\rho_{0}\left[\underset{\mathrm{EX} 1}{\left(\frac{\partial u}{\partial x}\right)^{2}}+\underset{\text { EX2 }}{\left(\frac{\partial v}{\partial y}\right)^{2}}\right. \\
& \left.+\left(\frac{\partial w}{\partial z}\right)^{2}-w^{2} \frac{\partial^{2}}{\partial z^{2}}\left(\ln \rho_{0}\right)\right] \\
& -2 \rho_{0}\left(\frac{\partial v}{\partial x} \frac{\partial u}{\partial y}+\frac{\partial u}{\partial z} \frac{\partial w}{\partial x}+\underset{\mathrm{SH} 2}{\frac{\partial v}{\partial z}} \frac{\partial w}{\partial y}\right),
\end{aligned}
$$

where the first right-hand-side term inside the brackets is the fluid extension term and the second is the shearing term. To- 
gether, Eqs. (11) and (13) are the Poisson equations of $p_{\mathrm{d}}^{\prime}$ and $p_{\mathrm{b}}^{\prime}$, and a maximum (minimum) in Laplacian corresponds to a minimum (maximum) in pressure perturbation. From Eq. (11), it can be seen that $p_{\mathrm{b}}^{\prime}$ is related to the vertical gradient of buoyancy $B$. While a variety of processes in Eq. (13) can lead to the change in $p_{\mathrm{d}}^{\prime}$, the fluid extension effect includes four terms: three terms from divergence/convergence and the fourth term linked to $w$ and the vertical gradient of $\rho_{0}$ (and will be referred to as EX1, EX2, EX3, and EX4, respectively). The fluid shearing effect consists of three terms related to horizontal wind shear and vertical shear of $u$ and $v$, respectively (referred to as $\mathrm{SH} 1, \mathrm{SH} 2$, and $\mathrm{SH} 3$ ), and $\mathrm{SH} 2$ and SH3 contain the shearing effect (of $\boldsymbol{S} \cdot \nabla_{\mathrm{h}} w$ ) mentioned in Sect. 1.1. After $\nabla^{2} p_{\mathrm{b}}^{\prime}, \nabla^{2} p_{\mathrm{d}}^{\prime}$, or any of its right-handside terms is obtained using Eqs. (11) or (13), the relaxation method is used to solve the associated pressure perturbation through iteration.

The results of $\nabla^{2} p^{\prime}$ obtained by the two different methods are compared in Fig. 12 at $547 \mathrm{~m}$ at 06:30 UTC, 8 August as an example. The patterns are generally very similar, with positive $\nabla^{2} p^{\prime}$ (implying $p^{\prime}<0$ ) to the east and negative $\nabla^{2} p^{\prime}$ (implying $p^{\prime}>0$ ) to the west of mature cells (e.g., A1 and B1) or positive $\nabla^{2} p^{\prime}$ at and to the south-southeast (SSE) of rising motion of developing cells and negative $\nabla^{2} p^{\prime}$ to the north-northwest (NNW, e.g., A2, B2, and C1). This suggests that the separation method described in Sect. 2.3 also gives reasonable results. However, the contrast between positive and negative $\nabla^{2} p^{\prime}$ values obtained from Eqs. (11) and (13) tends to be slightly larger. A comparison between Fig. $12 \mathrm{~b}$ with patterns of $\nabla^{2} p_{\mathrm{b}}^{\prime}$ and $\nabla^{2} p_{\mathrm{d}}^{\prime}$ indicates that $p^{\prime}$ is dominated by $p_{\mathrm{b}}^{\prime}$ (i.e., $p_{\mathrm{d}}^{\prime}$ is minimal) in most area (where $w$ is small) except near strong updrafts and downdrafts (not shown).

In Fig. 13, a closer view of the model-simulated vertical velocity $w$, the total pressure perturbation $p^{\prime}$ obtained through background separation and the relaxation method, as well as $p_{\mathrm{d}}^{\prime}$ through the relaxation method at (or near) three different heights of 550,1050, and $2050 \mathrm{~m}$ near cell A1 for the time at 06:30 UTC are shown, together with horizontal winds and vertical wind shear vector $\boldsymbol{S}$. Again, from the separation method, areas of $p^{\prime}<0$ at these three levels are typically found to the southern quadrants of the cell where ascending motion often also appears, while $p^{\prime}>0$ is generally to the north and weaker (Fig. 13a, d and g). The peak value of $p^{\prime}<0$ near the updraft is roughly $-1 \mathrm{hPa}$, and located to its SE at $550 \mathrm{~m}$ but to the southwest at $2050 \mathrm{~m}$. The patterns of total $p^{\prime}$ solved by the relaxation method at the three levels are generally similar, with $p^{\prime}<0$ to the SE and south of the updraft and $p^{\prime}>0$ to the north and northwest (NW, Fig. 13b, e and h). However, the N-S difference in $p^{\prime}$ surrounding the cell is considerably larger (near $3 \mathrm{hPa}$ inside the plotting domain) to give a lower value in minimum $p^{\prime}(\sim-1.5 \mathrm{hPa})$. The reason for this is most likely 2 -fold: (1) the variation in background pressure $p_{0}$ on the $x y$ plane at 06:30 UTC is larger than the time mean used, so that $p^{\prime}$
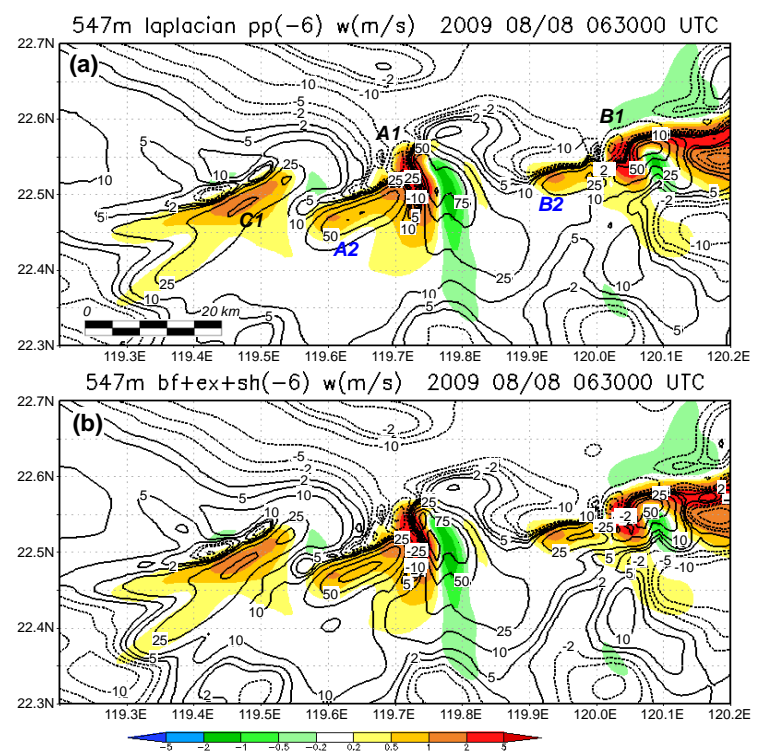

Figure 12. Model-simulated $w\left(\mathrm{~m} \mathrm{~s}^{-1}\right.$, color, scales at bottom) and (a) $\nabla^{2} p^{\prime}\left(10^{-6} \mathrm{~Pa} \mathrm{~m}^{-2}\right.$, contours, dashed for negative values) computed from $p^{\prime}$ using the separation method and (b) $\nabla^{2} p_{\mathrm{b}}^{\prime}+\nabla^{2} p_{\mathrm{d}}^{\prime}$ obtained by adding all the right-hand-side terms in Eqs. (11) and (13) together, at $547 \mathrm{~m}$ at 06:30 UTC, 8 August 2009. Contour levels are at $\pm 2, \pm 5, \pm 10, \pm 25, \pm 50, \pm 75$, and $\pm 100 \times 10^{-6} \mathrm{~Pa} \mathrm{~m}^{-2}$, respectively, and are the same in $(\mathbf{a}, \mathbf{b})$. The cells are labeled as in Fig. 8.

centers are under-estimated for this time using the separation method, and (2) the frictional effect that tends to reduce the contrast in $p^{\prime}$ is not taken into account in Eqs. (11)(13), causing some over-estimation in $p^{\prime}$ from the relaxation method. In agreement with earlier discussions (cf. Fig. 10a), the vertical shear across the updraft at $550 \mathrm{~m}$ is northwesterly to westerly and quite strong (roughly $1-2 \times 10^{-2} \mathrm{~s}^{-1}$, Fig. 13c) and a clear couplet in $p_{\mathrm{d}}^{\prime}$ can be found with $p_{\mathrm{d}}^{\prime}>0$ to the NW and $p_{\mathrm{d}}^{\prime}<0$ to the SE of the updraft, which can already reach about $5 \mathrm{~m} \mathrm{~s}^{-1}$ at this level (cf. Fig. 10b). Consistent with the gradual veering of environmental wind with height in the lower troposphere (cf. Figs. 5b and 13a, d and g) the vertical shear turns clockwise at 1050 and $2050 \mathrm{~m}$, and the alignment of the high-low couplet in $p_{\mathrm{d}}^{\prime}$ also gradually changes into NNW to SSE and even NNE to SSW (Fig. 13f and i). Although the vertical shear near $1-2 \mathrm{~km}$ is considerably weaker (mostly $<1 \times 10^{-2} \mathrm{~s}^{-1}$ ) than at $500 \mathrm{~m}$, the larger $w$ and its horizontal gradient allow for a comparable magnitude in $p_{\mathrm{d}}^{\prime}$ (cf. Fig. 10b). Thus, the patterns of $p_{\mathrm{d}}^{\prime}$ up to $2 \mathrm{~km}$ are consistent with the SH2 and SH3 terms in Eq. (13) and our hypothesis, and with a difference of about $0.6-1 \mathrm{hPa}$ across the high-low couplet, the dynamical pressure perturbations can account for a large part of the difference in total $p^{\prime}$ near the updraft (Fig. 13).

In Fig. 10a, it is seen that deep convection can locally modify the vertical wind profile and change the structure of the 

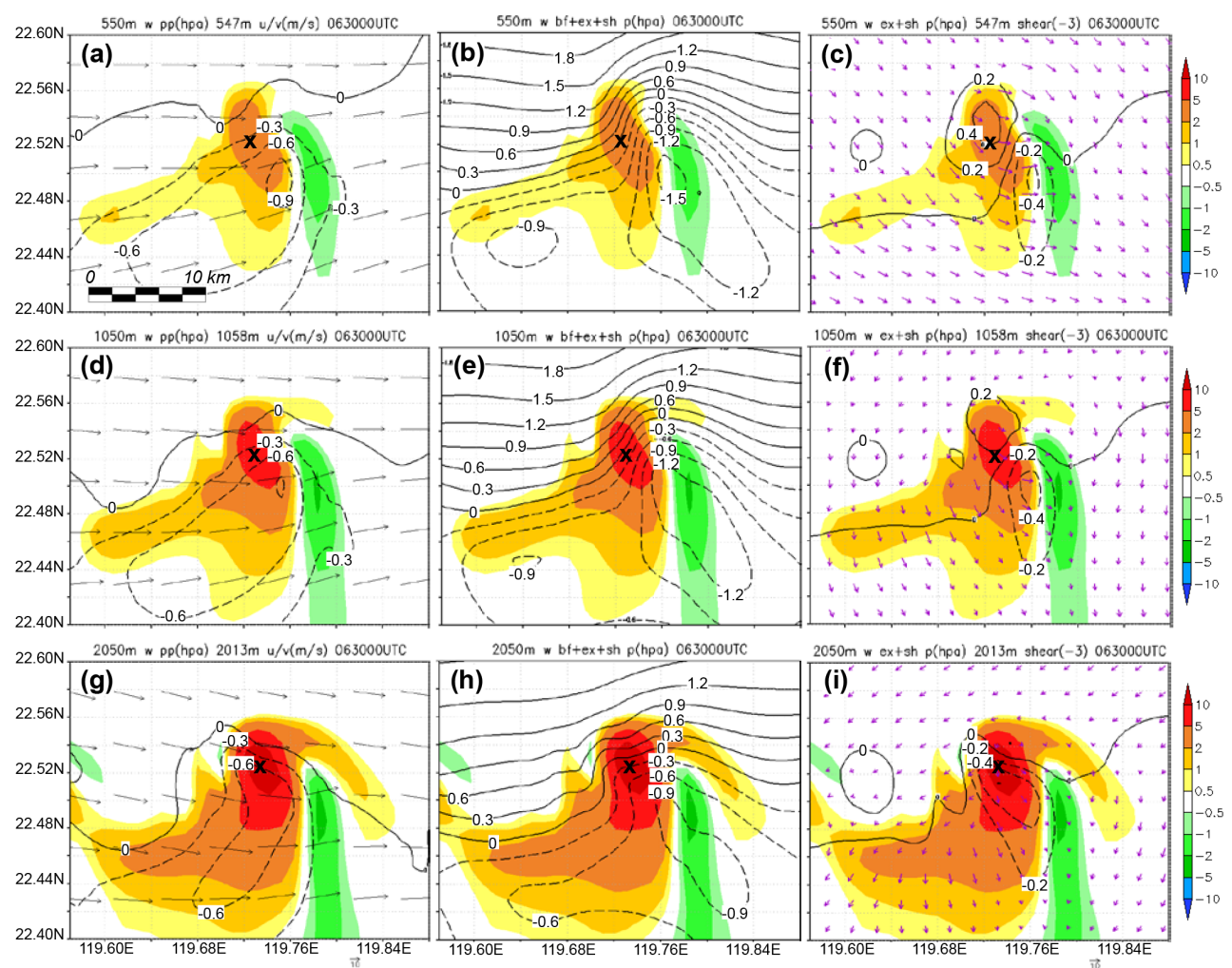

Figure 13. Model-simulated $w\left(\mathrm{~m} \mathrm{~s}^{-1}\right.$, color, scales on the right) and (a) total $p^{\prime}$ (hPa, contours, every $0.3 \mathrm{hPa}$, dashed for negative values) and horizontal winds $\left(\mathrm{m} \mathrm{s}^{-1}\right.$, vectors, reference vector at bottom), (b) $p_{\mathrm{b}}^{\prime}+p_{\mathrm{d}}^{\prime}\left(\mathrm{hPa}\right.$, contours) solved by the relaxation method, and (c) $p_{\mathrm{d}}^{\prime}$ ( $\mathrm{hPa}$, contours, every $0.2 \mathrm{hPa}$ ) solved by the relaxation method and vertical wind shear $\left(10^{-3} \mathrm{~s}^{-1}\right.$, purple vectors, reference vector at bottom) at $550 \mathrm{~m}$ at 06:30 UTC, 8 August 2009. (d-f) and $(\mathbf{g}-\mathbf{i})$ as in $(\mathbf{a}-\mathbf{c})$, except at 1050 and $2050 \mathrm{~m}$, respectively. For horizontal wind and vertical wind shear, vectors at the closest model output level (547, 1058, and $2013 \mathrm{~m}$, respectively) are plotted, and the " $\mathrm{x}$ " marks the updraft center in each panel.

LLJ, so here we examine such changes and the resultant effect on the shearing term in Eq. (13) in greater detail before further discussion on the pressure perturbations due to different terms. In Fig. 14, the E-W vertical cross sections as in Fig. 10b (along $22.52^{\circ} \mathrm{N}$ ) but for kinematic variables, vertical wind shear, and $\nabla^{2} p_{\mathrm{d}}^{\prime}$ from $\mathrm{SH} 2$ are presented. In Fig. 14a, it can be clearly seen that the low-level convergence induced by the mature cell A1 also causes the LLJ to accelerate toward the updraft and decelerate beneath the updraft core. The upward transport of momentum inside the updraft ( $\sim 6 \mathrm{~km}$ in width), consistent with its eastward tilt with height, also elevates the jet to $2-4 \mathrm{~km}$. Due to the formation of the tilted maximum-minimum wind couplet (Fig. 14a), the vertical wind shear directly below the updraft core is enhanced (near $119.71-119.75^{\circ} \mathrm{E}$ and below $1 \mathrm{~km}$, Fig. 14b). Associated with the rise of the LLJ, the northwesterly shear above the jet core at the western flank of the updraft (near $119.72^{\circ}, 2-4 \mathrm{~km}$ ) is also strengthened to some extent. In response to this profile of vertical wind shear modified by convection, the pattern of $\nabla^{2} p_{\mathrm{d}}^{\prime}$ from SH2 (multiplied by -1 to have the same sign as $p_{\mathrm{d}}^{\prime}$ ) exhibits positive $p_{\mathrm{d}}^{\prime}$ below 1$1.5 \mathrm{~km}$ to the west and negative $p_{\mathrm{d}}^{\prime}$ below $\sim 3 \mathrm{~km}$ to the east of the updraft center, and a reversed pattern above to at least $5 \mathrm{~km}$ (Fig. 14b), again consistent with our hypothesis.

Figure 15 presents the total $p^{\prime}$ from background separation and $p_{\mathrm{b}}^{\prime}$ and $p_{\mathrm{d}}^{\prime}$ and the major contributing terms of $p_{\mathrm{d}}^{\prime}$ from the relaxation method along the same E-W vertical crosssection as Fig. 14, in addition to $w$. The total $p^{\prime}$ associated with cell A1 obtained from the two different methods have similar patterns on the vertical plain (Fig. 15a and b), with largest negative $p^{\prime}$ of about $-1 \mathrm{hPa}$ near 3-4 km and higher $p^{\prime}$ at the surface immediately to the west of the updraft core. Directly underneath the updraft and to its east, on the other hand, $p^{\prime}$ obtained through the relaxation method is smaller (more negative) near the surface, which is mainly due to the effects of $p_{\mathrm{b}}^{\prime}$ rather than $p_{\mathrm{d}}^{\prime}$ (Fig. $15 \mathrm{c}$ and d). To the west of the updraft, however, $p_{\mathrm{d}}^{\prime}$ is the main reason for the total $p^{\prime}$ to become positive near the surface and negative further aloft as expected (Fig. 15a-c), and the major contributing terms to this pattern is the shearing and divergent effects of the updraft $(\mathrm{SH} 2+$ EX3, Fig. 15e and f), in agreement with Fig. 14. The region of $p_{\mathrm{b}}^{\prime}<0$ below and east of the updraft at low levels is resulted from an increase in buoyancy $B$ with height (i.e., $\nabla^{2} p_{\mathrm{b}}^{\prime}>0$, cf. Eqs. 7 and 11). On this section plane, 

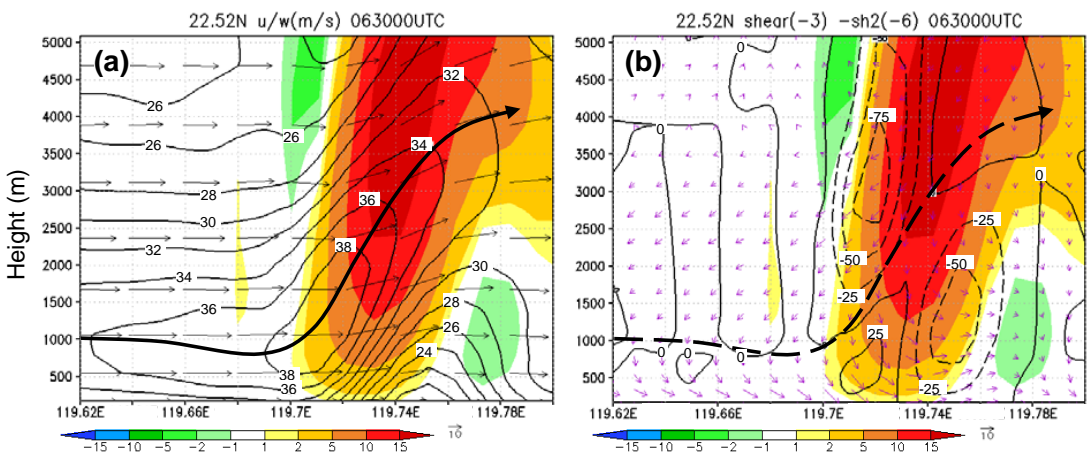

Figure 14. E-W vertical cross sections, through cell A1, of model-simulated $w\left(\mathrm{~m} \mathrm{~s}^{-1}\right.$, color, scale at bottom) and (a) wind vectors on the section plane $\left(\mathrm{m} \mathrm{s}^{-1}\right.$, reference vector at bottom), and $u$ wind speed $\left(\mathrm{m} \mathrm{s}^{-1}\right.$, isotachs, every $\left.2 \mathrm{~m} \mathrm{~s}^{-1}\right)$ and (b) vertical wind shear $\left(10^{-3} \mathrm{~s}^{-1}\right.$, purple vectors, reference vector at bottom) and -1 times the $x$ component of shearing term in Eq. (13) $\left(10^{-6} \mathrm{~Pa} \mathrm{~m}^{-2}\right.$, every $25 \times 10^{-6} \mathrm{~Pa} \mathrm{~m}^{-2}$, dashed for negative values) along $22.52^{\circ} \mathrm{N}$ from 119.62 to $119.8^{\circ} \mathrm{E}$ (about $18 \mathrm{~km}$ in length) at 06:30 UTC, 8 August 2009. The thick (dashed) arrow lines in (a) and (b) mark the axis of LLJ.

right-hand-side terms in Eq. (13) other than SH2 and EX3 are much smaller, especially EX4 which is about 2 orders of magnitude smaller. Thus, these other terms are not shown.

\section{Discussion}

In the previous section, the dynamical pressure perturbation $p_{\mathrm{d}}^{\prime}$ near the updraft of the mature cell in the rainband is found to exhibit a pattern consistent with our hypothesis, i.e., with positive (negative) perturbation below (above) the LLJ upwind from the updraft, and this pattern is attributed mainly to the shearing effect of the updraft on the vertical wind shear associated with the jet (SH2) but also to the extension term from vertical acceleration inside the tilted updraft (EX3). The induced PGF by the total $p^{\prime}$ and its components $\left(p_{\mathrm{b}}^{\prime}\right.$ and $p_{\mathrm{d}}^{\prime}$ ) in the vertical can be computed using Eq. (8), and this is shown in Fig. 16 on the same cross section through cell A1 (along $22.52^{\circ} \mathrm{N}$ ). With its pattern shown in Fig. 15c, the high-low couplet of $p_{\mathrm{d}}^{\prime}$ west of the updraft induces an upward-directed PGF there below about $3 \mathrm{~km}$, with a peak value of roughly $7 \times 10^{-2} \mathrm{~m} \mathrm{~s}^{-2}$ at $1.5 \mathrm{~km}$ (Fig. 16a). Such acceleration can produce an upward motion of $5 \mathrm{~m} \mathrm{~s}^{-1}$ under $75 \mathrm{~s}$, or from 5 to $15 \mathrm{~m} \mathrm{~s}^{-1}$ in $150 \mathrm{~s}$ across a distance of about $1.5 \mathrm{~km}$, very comparable to the acceleration below the core of the main updraft. Consistent with this result, cell A1 maintains its strength but travels at a slower speed after 06:30 UTC (cf. Figs. 8 and 17). Thus, the distribution of $p_{\mathrm{d}}^{\prime}$ to the rear side of the updraft can certainly affect the evolution of cell A1 and cause it to slow down in moving speed. In other words, the cell merging behavior in the rainbands consisting of multiple cells, when they develop in an environment with an intense LLJ as in the present case, can be explained by the mechanism of dynamical pressure perturbations induced through the shearing (and extension) effect. In Figs. 15 and 16, by strengthening the upward acceleration in the updraft, the shearing effect appears to also act to reinforce the fluid extension term (EX3) in Eq. (13). In addition to its role in cell merging, the reduced propagation speed of mature cells implies an enhancement in low-level convergence upstream. Using Fig. 8 (A1 traveling at $26.1 \mathrm{~m} \mathrm{~s}^{-1}$ ) and assuming a LLJ of $35 \mathrm{~m} \mathrm{~s}^{-1}$ about $40 \mathrm{~km}$ upstream (cf. Fig. 10a), the speed convergence implied is about $2.2 \times 10^{-4} \mathrm{~s}^{-1}$, or $3.2 \times 10^{-4} \mathrm{~s}^{-1}$ larger than the background with speed divergence of $\sim 1 \times 10^{-4} \mathrm{~s}^{-1}$

Because of the surface-based negative $p_{\mathrm{b}}^{\prime}$ below and east of the updraft, the induced vertical PGF by $p_{\mathrm{b}}^{\prime}$ is also negative (directed downward) below $3 \mathrm{~km}$ (Figs. 15d and 16b), suggesting that the downwind side of the updraft is less favorable for its maintenance and further development. The buoyancy $B$ is mostly positive inside the updraft (Fig. 16c) and this can only come from an increased $\theta_{v}^{\prime}$ due to latent heat release (cf. Eq. 7). Although $B$ is also positive below the updraft core and even to the west (below $1 \mathrm{~km}$ ), its values are smaller than the upward acceleration induced by the $p_{\mathrm{d}}^{\prime}$ pattern and largely canceled by the effect of $p_{\mathrm{b}}^{\prime}$ (Fig. 16d). Thus, when all three terms in Fig. 16a-c are added together in Fig. 16e, their total effect on vertical acceleration (cf. Eq. 8) resembles that from the effect of $p_{\mathrm{d}}^{\prime}$ alone in both the pattern and magnitude (cf. Fig. 16a).

The patterns of $p^{\prime}, p_{\mathrm{d}}^{\prime}$, and $p_{\mathrm{b}}^{\prime}$, their induced perturbation PGF in the vertical, and $B$ in association with the mature cell, as shown in Figs. 15 and 16, are also quite persistent through time. For example, at 06:45 UTC when A2 grows significantly stronger (cf. Fig. 8), the distributions of $p_{\mathrm{d}}^{\prime}$ (Fig. 17a) and vertical accelerations from the dynamical (Fig. 17b), total buoyant (Fig. 17c), and their combined effects (Fig. 17d) along the E-W cross section (through A1) all remain similar to those 15 min earlier (cf. Figs. $15 \mathrm{c}$ and 16a, $\mathrm{d}$, and e, respectively), although some of them have weakened somewhat. The effects of $p_{\mathrm{d}}^{\prime}$, nevertheless, still dominate over those from $p_{\mathrm{b}}^{\prime}$ and $B$ at the rear side of cell A1. 

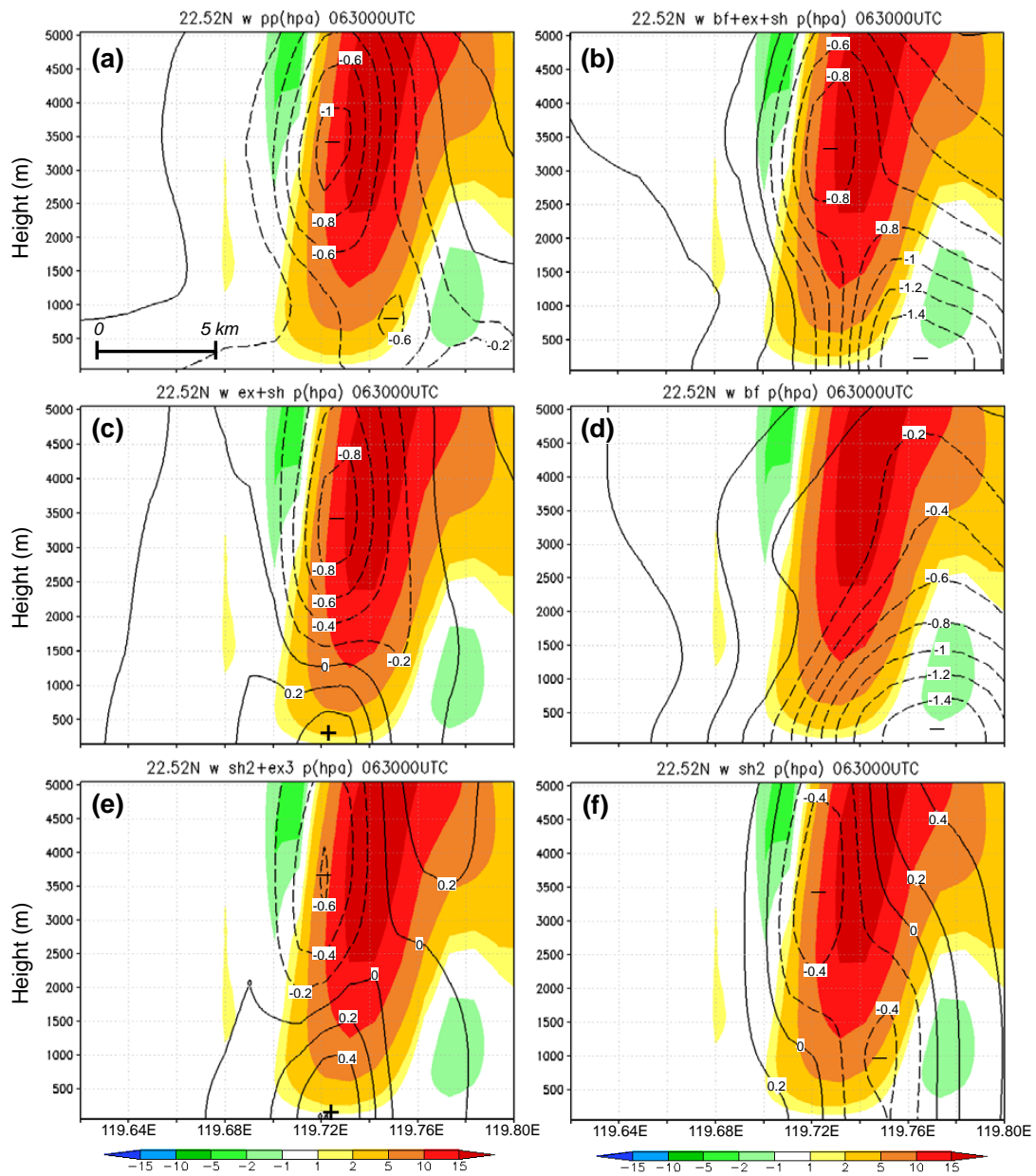

Figure 15. As in Fig. 14, except for $w\left(\mathrm{~m} \mathrm{~s}^{-1}\right.$, color, scale at bottom) and (a) total $p^{\prime}$ (hPa, contours, every $0.2 \mathrm{hPa}$, dashed for negative values) separated from the background, and (b) $p_{\mathrm{b}}^{\prime}+p_{\mathrm{d}}^{\prime}$, (c) $p_{\mathrm{d}}^{\prime}$, (d) $p_{\mathrm{b}}^{\prime}$, (e) the portion of $p_{\mathrm{d}}^{\prime}$ from SH2 and EX3, and (f) the portion of $p_{\mathrm{d}}^{\prime}$ from $\mathrm{SH} 2$ alone (all in $\mathrm{hPa}$, contours) in Eq. (13) solved by the relaxation method. The positive and negative centers are labeled by plus and minus signs, respectively.

Similar results are also found in mature cells in other rainbands (not shown).

From Fig. $15 \mathrm{c}$ and e, the positive $p_{\mathrm{d}}^{\prime}$ near the surface can be seen to also produce horizontal PGF apart from the vertical PGF, and the westward-directed PGF upstream from A1 (west of $119.7^{\circ} \mathrm{E}$ ) can be estimated using Eq. (5) to be about $3-7 \times 10^{-3} \mathrm{~m} \mathrm{~s}^{-2}$, which is about 1 order of magnitude smaller than the PGF in the vertical from $p_{\mathrm{d}}^{\prime}$. Nevertheless, a value of $5 \times 10^{-3} \mathrm{~m} \mathrm{~s}^{-2}$ is enough to decelerate the oncoming westerly flow by $1 \mathrm{~m} \mathrm{~s}^{-1}$ in $200 \mathrm{~s}$ and induce a speed convergence of roughly $1.4 \times 10^{-4} \mathrm{~s}^{-1}$ (again assuming a background flow of $35 \mathrm{~m} \mathrm{~s}^{-1}$ ). Even though this value is 1 order of magnitude smaller than the convergence associated with cell A2 at 06:30 UTC during its early stage of development $\left(\sim 1.5 \times 10^{-3} \mathrm{~s}^{-1}\right.$, cf. Fig. 9 a) the combined convergence with that implied by a slower moving speed of A1 (as discussed earlier) would be about $4.6 \times 10^{-4} \mathrm{~s}^{-1}$ larger compared to its surrounding. This is certainly not negligi- ble and can provide additional forcing to favor new cell development upstream from the old cell, consistent with the time evolution of A2 (Figs. 8 and 17). Therefore, the role played by the dynamical pressure perturbation in producing an anomalous high near the surface and additional uplift at the rear flank of the updraft of mature cells can favor both merging and new cell initiation further upstream, i.e., the behavior commonly found in back-building MCSs, in the rainbands of TY Morakot (2009) when a strong LLJ is present in the background. Since the LLJ is a common feature in the TC environment, our results are likely also applicable to cell evolution in the rainbands of other TC cases.

In the Mei-yu season (May-June), quasi-linear MCSs also often develop near the Mei-yu front in an environment with a LLJ (e.g., Chen, 1992; Chen and Chou, 1993; Chen et al., 2005; Wang et al., 2014), and they may exhibit characteristics reminiscent to the TL/AS or BB systems described by Schumacher and Johnson $(2005,2006)$ and cause heavy 

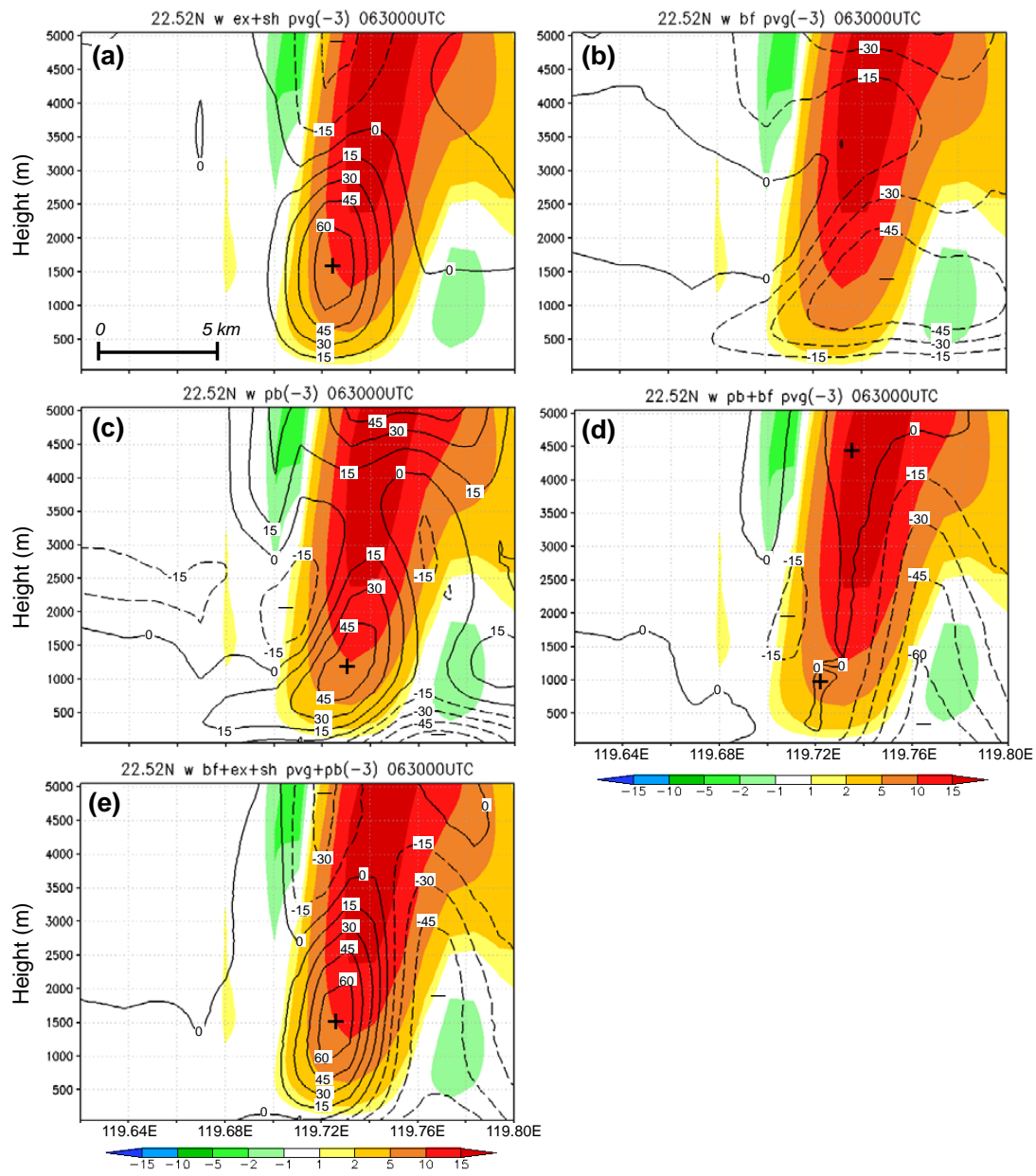

Figure 16. As in Fig. 14, except for $w\left(\mathrm{~m} \mathrm{~s}^{-1}\right.$, color, scale at bottom) and the vertical $(z)$ component of perturbation pressure gradient force $\left(10^{-3} \mathrm{~m} \mathrm{~s}^{-2}\right.$, contours, every $15 \times 10^{-3} \mathrm{~m} \mathrm{~s}^{-2}$, dashed for negative values) from (a) $p_{\mathrm{d}}^{\prime}$, (b) $p_{\mathrm{b}}^{\prime}$, (c) buoyancy $(B)$, (d) $p_{\mathrm{b}}^{\prime}+B$, and (e) $p_{\mathrm{d}}^{\prime}+p_{\mathrm{b}}^{\prime}+B$, respectively. The positive and negative centers are labeled by plus and minus signs, respectively.

rainfall and flash floods (e.g., Lin et al., 1992; Wang et al., 2005; Jou et al., 2011). Thus, although typhoon rainbands are studied here and the LLJs are typically not as strong in the Mei-yu season, a similar interaction between the updrafts and LLJ may promote cell merging and initiation of new cells upstream, and thus contribute to heavy rainfall and related weather hazards.

\section{Conclusion and summary}

Typhoon Morakot in August 2009 was the most devastating TC to hit Taiwan over the past 50 years, with extreme rainfall that came close to the 24 and $48 \mathrm{~h}$ world records. During the period of heaviest rainfall on 8 August, when the TC center was over the northern Taiwan Strait, the E-W oriented, persistent, and slow-moving rainbands and the embedded deep convection that propagated eastward (parallel to the bands) were responsible for the serious and wide-spread flooding over the southwestern plains of Taiwan. Developing inside the low-level convergence zone between the TC vortex (from the N-NW-W) and the monsoon flow (from the WSW-SW) over the southern strait, as also observed in several other past TCs, these rainbands were collocated with a westerly LLJ and exhibited frequent cell merging and back-building behavior that contributed to the heavy rainfall. Thus, the possible roles of pressure perturbations associated with deep convection on rainband behavior of TY Morakot (2009) are investigated in this study, mainly through the use of simulation results from the CReSS model at a horizontal grid-spacing of $1 \mathrm{~km}$ every $7.5 \mathrm{~min}$.

In the model, the rainbands, multiple cells embedded, their eastward movement, and merging and back-building behavior are all successfully captured in close agreement with the observations, although slight positional errors are often unavoidable. In its mature stage, a particular cell at 06:00 UTC, 8 August is selected for detailed study. As hypothesized (cf. Fig. 6) following Rotunno and Klemp (1982) and Klemp (1987), in an environment of a LLJ $\left(\sim 35 \mathrm{~m} \mathrm{~s}^{-1}\right)$ 

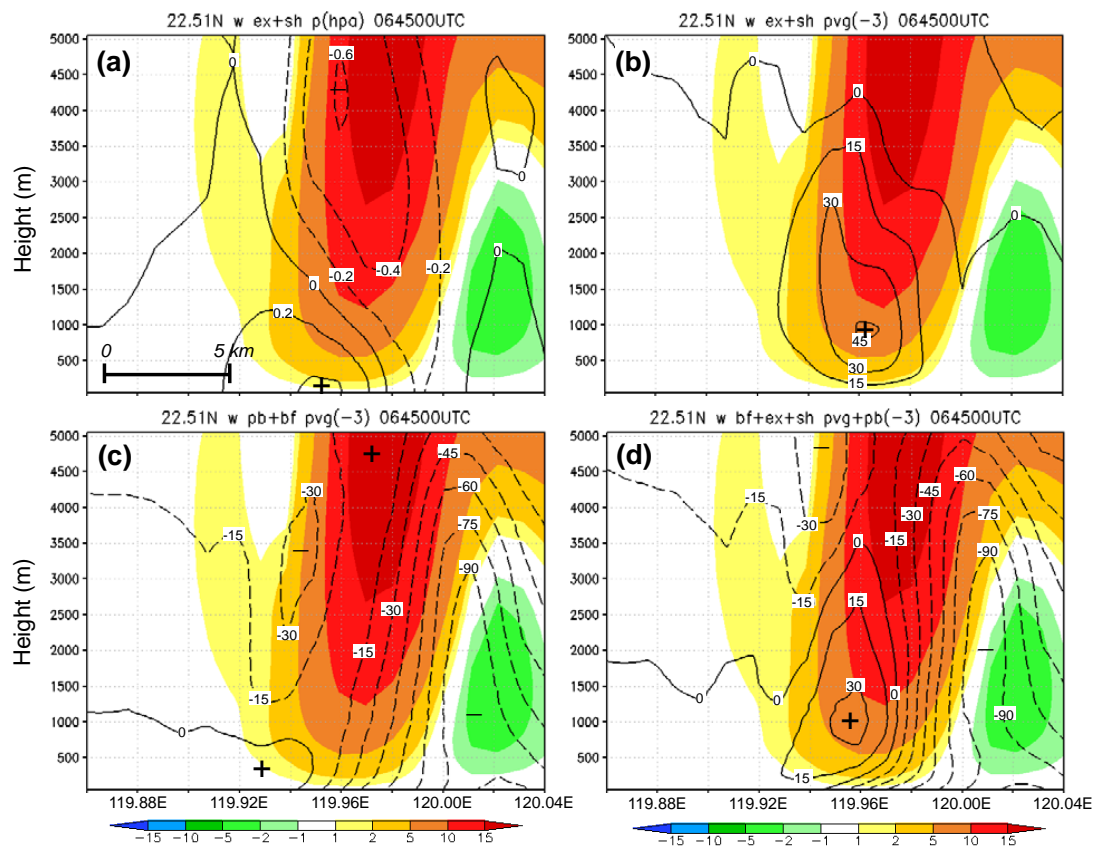

Figure 17. (a) As in Fig. 15c, except for $w\left(\mathrm{~m} \mathrm{~s}^{-1}\right.$, color) and $p_{\mathrm{d}}^{\prime}\left(\mathrm{hPa}\right.$, contours, every $0.2 \mathrm{hPa}$ ) along $22.51^{\circ} \mathrm{N}$ from 119.86 to $120.04^{\circ} \mathrm{E}$ (about $18 \mathrm{~km}$ in length) at 06:45 UTC, 8 August 2009. (b-d) As in Fig. 16, except for $w$ and the $z$ component of perturbation pressure gradient force $\left(10^{-3} \mathrm{~m} \mathrm{~s}^{-2}\right.$, contours, every $\left.15 \times 10^{-3} \mathrm{~m} \mathrm{~s}^{-2}\right)$ from (b) $p_{\mathrm{d}}^{\prime}$, (c) $p_{\mathrm{b}}^{\prime}+B$, and (d) $p_{\mathrm{d}}^{\prime}+p_{\mathrm{b}}^{\prime}+B$, respectively, at 06:45 UTC along the same cross-section as (a).

with reversed vertical wind shear below and above, the interaction between convective updraft and such a vertical shear profile produces a positive dynamical pressure perturbation $p_{\mathrm{d}}^{\prime}$ to the west (rear) and a negative $p_{\mathrm{d}}^{\prime}$ to the east of the updraft near the surface $(\sim 500 \mathrm{~m})$, but $p_{\mathrm{d}}^{\prime}<0$ to the west and $p_{\mathrm{d}}^{\prime}>0$ to the east farther aloft above the jet core $(>2 \mathrm{~km})$. At the rear side, the positive-negative couplet of $p_{\mathrm{d}}^{\prime}$ in the vertical has a difference of about $1 \mathrm{hPa}$ in $p$, and induces an upward-directed PGF, of which the magnitude is comparable to the acceleration inside the updraft core. This configuration favors updraft development at the rear flank, and subsequently causes the mature cells to slow down and merge with approaching new cells, which remain faster without a strong updraft. The intense updraft of this mature cell, reaching $10 \mathrm{~m} \mathrm{~s}^{-1}$ at $1.3 \mathrm{~km}$ and about $20 \mathrm{~m} \mathrm{~s}^{-1}$ at mid-level, is also found to elevate the jet and act to enhance the local vertical wind shear both above and below the jet core at its rear flank, aided by the induced near-surface convergence at cloud scale.

Through the use of the relaxation method to solve for each contributing terms of $p_{\mathrm{d}}^{\prime}$ (and the buoyancy perturbation pressure $p_{\mathrm{b}}^{\prime}$, where $p^{\prime}=p_{\mathrm{d}}^{\prime}+p_{\mathrm{b}}^{\prime}$ ), our results indicate that the above vertical couplet of $p_{\mathrm{d}}^{\prime}$ to the rear flank is mainly caused by the shearing effect (SH2 in Eq. 13, or $\left.-2 \rho_{0}(\partial u / \partial z)(\partial w / \partial x)\right)$, but also contributed by the vertical extension term (EX3 in Eq. 13, or $\left.-\rho_{0}(\partial w / \partial z)^{2}\right)$, i.e., by the upward acceleration in the updraft, at low levels, while the effect of $p_{\mathrm{b}}^{\prime}$ is nearly counteracted by the buoyancy $B$ in the mature cell examined. Near the surface, the westwarddirected horizontal PGF induced by the positive $p_{\mathrm{d}}^{\prime}$ at the rear side, when combined with the effect from the slowing down of mature cells, can produce an estimated additional convergence (in speed) roughly $1 / 4-1 / 3$ of the value associated with developing new cell further upstream. Thus, a positive $p_{\mathrm{d}}^{\prime}$ near the surface in the couplet is also helpful to new cell initiation some distance upstream, i.e., the back-building process, compared to the conditions without a mature cell. Finally, the updraft in the mature cell in our case tilts eastward (downwind) with height due to the presence of the LLJ, and the maximum precipitation and near-surface downdraft occur at the eastern side. However, only a weak cold pool is found since the low-level air is very moist and a dry layer does not exist at mid-levels in the TC environment. Thus, the cold-pool mechanism typical in mid-latitudes to initiate new cells in back-building systems does not appear to be important in our case here.

Acknowledgements. The authors are grateful to the valuable comments from Russ Schumacher (Colorado State University), Chris Rozoff (University of Wisconsin-Madison), and an anonymous reviewer that help improve this work. The authors also wish to acknowledge Ching-Hwang Liu (Chinese Culture University, Taiwan) in providing Fig. 4, the Central Weather Bureau (CWB) in providing Fig. 2a and the panels used in Fig. $3 \mathrm{~b}$ (as well as nearly all observational data), and the assistance from K.-Y. Chen and Y.-W. Wang in figure editing. This study is jointly supported by 
the Ministry of Science and Technology of Taiwan under grants NSC-102-2119-M-003-003, MOST-103-2119-M-003-001-MY2, MOST 104-2111-M-002-002-MY3, MOST 103-2625-M-002-003, and MOST 103-2111-M-002-010, by the Office of Naval Research Global under Grant N62909-15-1-2008, and by National Taiwan University under Grant NTU-CESRP-104R7064-1.

Edited by: H. Wernli

\section{References}

Anthes, R. A.: Tropical Cyclones. Their Evolution, Structure and Effects, Meteor. Monogr., No. 41, American Meteorological Society, Boston, MA, USA, 208 pp., 1982.

Bluestein, H. B. and Jain, M. H.: Formation of mesoscale lines of precipitation: Severe squall lines in Oklahoma during the spring, J. Atmos. Sci., 42, 1711-1732, 1985.

Brooks, H. E. and Stensrud, D. J.: Climatology of heavy rain events in the United States from hourly precipitation observations. Mon. Weather Rev., 128, 1194-1201, 2000.

Browning, K. A.: Organization of clouds and precipitation in extratropical cyclones, in: Extratropical Cyclones: The Erik Palmén Memorial Volume, edited by: Newton, C. W. and Holopanien, E. O., Boston, MA, USA, Am. Meteor. Soc., 129-153, 1990.

Carbone, R. E.: A severe frontal rainband. Part I: Stormwide hydrodynamic structure, J. Atmos. Sci., 39, 258-279, 1982.

Corfidi, S. F., Meritt, J. H., and Fritsch, J. M.: Predicting the movement of mesoscale convective complexes, Weather Forecast., 11, 41-46, 1996.

Chang, C.-P., Yang, Y.-T., and Kuo, H.-C.: Large increasing trend of tropical cyclone rainfall in Taiwan and the roles of terrain, J. Climate, 26, 4138-4147, 2013.

Chappell, C. F.: Quasi-stationary convective events, in: Mesoscale Meteorology and Forecasting, edited by: Ray, P., American Meteorological Society, Boston, MA, USA, 289-310, 1986.

Chen, G. T.-J.: Mesoscale features observed in the Taiwan Mei-Yu season, J. Meteorol. Soc. Jpn., 70, 497-516, 1992.

Chen, G. T.-J. and Chou, H.-C.: General characteristics of squall lines observed in TAMEX, Mon. Weather Rev., 121, 726-733, 1993.

Chen, G. T.-J., Wang, C.-C., and Lin, D. T.-W.: Characteristics of low-level jets over northern Taiwan in Mei-yu season and their relationship to heavy rain events, Mon. Weather Rev., 133, 2043, 2005.

Chen, T.-C., Wei, C.-H., Lin, P.-L., and Liou, Y.-C.: The characteristics of radar-observed mesoscale rainbands of Typhoon Morakot, in: Scientific Report on Typhoon Morakot (2009), edited by: Hsu, H.-H., Kuo, H.-C., Jou, J.-D., Chen, T.-C., Lin, P.-H., Yeh, T.-C., and Wu, C.-C., National Science Council, Taipei, Taiwan, 53-81, 2010 (in Chinese).

Chien, F.-C. and Kuo, H.-C.: On the extreme rainfall of Typhoon Morakot (2009), J. Geophys. Res., 116, D05104, doi:10.1029/2010JD015092, 2011.

Chien, F.-C., Liu, Y.-C., and Lee, C.-S.: Heavy rainfall and southwesterly flow after the leaving of Typhoon Mindulle (2004) from Taiwan, J. Meteorol. Soc. Jpn., 86, 17-41, 2008.

Doswell III, C. A.: Severe convective storms - An overview, in: Severe Convective Storms, Meteor. Monogr., Boston, MA, USA, edited by: Doswell, C. A. III, ISBN: 978-1-878220-41-7, No. 50, Amer. Meteor. Soc., 1-26, 2001.

Doswell III, C. A., Brooks, H. E., and Maddox, R. A.: Flash flood forecasting: An ingredients-based methodology. Weather Forecast., 11, 560-581, 1996.

Eastin, M. D. and Link, M. C.: Miniature supercells in an offshore outer rainband of Hurricane Ivan (2004), Mon. Weather Rev., 137, 2081-2104, 2009.

Garstang, M., Massie Jr., H. L., Halverson, J., Greco, S., and Scala, J.: Amazon coastal squall lines. Part I: Structure and kinematics, Mon. Weather Rev., 122, 608-622, 1994.

Guhathakurta, P.: Highest recorded point rainfall over India, Weather, 62, p. 349, doi:10.1002/wea.154, 2007.

Hawkins, H. F. and Imbembo, S. M.: The structure of a small, intense hurricane - Inez 1966, Mon. Weather Rev., 140, 418-442, 1976.

Hence, D. A. and Houze Jr., R. A.: Kinematic structure of convective-scale elements in the rainbands of Hurricanes Katrina and Rita (2005), J. Geophys. Res., 113, D15108, doi:10.1029/2007JD009429, 2008.

Hendricks, E. A., Moskaitis, J. R., Jin, Y., Hodur, R. M., Doyle, J. D., and Peng, M. S.: Prediction and diagnosis of Typhoon Morakot (2009) using the Naval Research Laboratory's mesoscale tropical cyclone model, Terr. Atmos. Oceanic Sci., 22, 579-594, doi:10.3319/TAO.2011.05.30.01(TM), 2011.

Holland, G. J.: WMO/TC-No. 560, Report No. TCP-31, World Meteorological Organization, Geneva, Switzerland, 1993.

Hong, C.-C., Lee, M.-Y., Hsu, H.-H., and Kuo, J.-L.: Role of submonthly disturbance and 40-50 day ISO on the extreme rainfall event associated with Typhoon Morakot (2009) in southern Taiwan, Geophys. Res. Lett., 37, L08805, doi:10.1029/2010GL042761, 2010.

Houston, A. L. and Wilhelmson, R. B.: Observational analysis of the 27 May 1997 central Texas tornadic event. Part I: Prestorm environment and storm maintenance/propagation, Mon. Weather Rev., 135, 701-726, 2007.

Houze Jr., R. A.: Structure and dynamics of a tropical squall-line system, Mon. Weather Rev., 105, 1540-1567, 1977.

Houze Jr., R. A.: Clouds in tropical cyclones, Mon. Weather Rev., 138, 293-344, 2010.

Houze Jr., R. A., Smull, B. F., and Dodge, P.: Mesoscale organization of springtime rainstorms in Oklahoma, Mon. Weather Rev., 118, 613-654, 1990.

Hsu, H.-H., Kuo, H.-C., Jou, J.-D., Chen, T.-C., Lin, P.-H., Yeh, T.C., and Wu, C.-C.: Scientific report on Typhoon Morakot (2009), National Science Council, Taipei, Taiwan, 192 pp., 2010 (in Chinese).

Hsu, J.: ARMTS up and running in Taiwan, Väisälä News, 146, 24 26, 1998.

Hsu, L.-H., Kuo, H.-C., and Fovell, R. G.: On the geographic asymmetry of typhoon translation speed across the mountainous island of Taiwan, J. Atmos. Sci., 70, 1006-1022, 2013.

Huang, H.-L., Yang, M.-J., and Sui, C.-H.: Water budget and precipitation efficiency of Typhoon Morakot (2009), J. Atmos. Sci., 71, 112-129, 2014.

Johnson, R. H. and Mapes, B. E.: Mesoscale processes and severe convective weather, Severe Convective Storms, Meteor. Monogr., No. 50, Amer. Meteor. Soc., 71-122, 2001. 
Jou, B. J.-D., Lee, W.-C., and Johnson, R. H.: An overview of SoWMEX/TiMREX and its operation, in: The Global Monsoon System: Research and Forecast, edited by: Chang, C.-P., Ding, Y., Lau, N.-C., Johnson, R. H., Wang, B., and Yasunari, T., 2nd Edn., World Scientific, Singapore, 303-318, 2011.

Klemp, J. B.: Dynamics of tornadic thunderstorms, Annu. Rev. Fluid Mech., 19, 369-402, 1987.

Kuo, H.-C., Yang, Y.-T., and Chang, C.-P.: Typhoon Morakot (2009): Interplay of southwest monsoon, terrain, and mesoscale convection, Int. Workshop on Typhoon Morakot (2009), Taipei, Taiwan, National Science Council and National Applied Research Laboratories, Taipei, Taiwan, 25-26 March 2010, p. 55, 2010.

Lee, C.-S., Wu, C.-C., Chen, T.-C., and Elsberry, R. L.: Advances in understanding the "perfect monsoon-influenced typhoon": summary from international conference on typhoon Morakot (2009), Asian-Pacific J. Atmos. Sci., 47, 213-222, 2011.

LeMone, M. A., Zipser, E. J., and Trier, S. B.: The role of environmental shear and thermodynamic conditions in determining the structure and evolution of mesoscale convective systems during TOGA COARE, J. Atmos. Sci., 55, 3493-3518, 1998.

Lin, Y.-J., Pasken, R. W., and Chang, H.-W.: The structure of a subtropical prefrontal convective rainband. Part I: Mesoscale kinematic structure determined from dual-Doppler measurements, Mon. Weather Rev., 120, 1816-1836, 1992.

Luo, Y., Gong, Y., and Zhang, D.-L.: Initiation and organizational modes of an extreme-rain-producing mesoscale convective system along a Mei-yu front in East China, Mon. Weather Rev., 142, 203-221, 2014.

Meng, Z., Yan, D., and Zhang, Y.: General features of squall lines in East China, Mon. Weather Rev., 141, 1629-1647, 2013.

Moncrieff, M. W.: The multiscale organization of moist convection and the intersection of weather and climate. Why Does Climate Vary?, Geophys. Monogr., 189, Amer. Geophys. Union, 3-26, 2010.

Moore, B. J., Neiman, P. J., Ralph, F. M., and Barthold, F. E.: Physical processes associated with heavy flooding rainfall in Nashville, Tennessee, and vicinity during 1-2 May 2010: The role of an atmospheric river and mesoscale convective systems, Mon. Weather Rev., 140, 358-378, 2012.

Morin, M. J. and Parker, M. D.: A numerical investigation of supercells in landfalling tropical cyclones, Geophys. Res. Lett., 38, L10801, doi:10.1029/2011GL047448, 2011.

Murphy Jr., M. J. and Businger, S.: Orographic influences on an Oahu flood, Mon. Weather Rev., 139, 2198-2217, 2011.

Nguyen, H. V. and Chen, Y.-L.: High-resolution initialization and simulations of Typhoon Morakot (2009), Mon. Weather Rev., 139, 1463-1491, 2011.

Parker, M. D. and Johnson, R. H.: Organizational modes of midlatitude mesoscale convective systems, Mon. Weather Rev., 128, 3413-3436, 2000.

Parker, M. D. and Johnson, R. H.: Structures and dynamics of quasi2D mesoscale convective systems, J. Atmos. Sci., 61, 545-567, 2004.

Peters, J. M. and Roebber, P. J.: Synoptic control of heavy-rainproducing convective training episodes, Mon. Weather Rev., 142, 2464-2482, 2014.

Quetelard, H., Bessemoulin, P., Cerveny, R. S., Peterson, T. C., Burton, A., and Boodhoo, Y.: Extreme weather: World-record rain- falls during Tropical Cyclone Gamede, B. Am. Meteorol. Soc., 90, 603-608, 2009.

Rotunno, R. and Klemp, J. B.: The influence of the shear-induced pressure gradient on thunderstorm motion, Mon. Weather Rev., 110, 136-151, 1982.

Rotunno, R., Klemp, J. B., and Weisman, M. L.: A theory for strong, long-lived squall lines, J. Atmos. Sci., 45, 463-485, 1988.

Schumacher, R. S. and Johnson, R. H.: Organization and environmental properties of extreme-rain-producing mesoscale convective systems, Mon. Weather Rev., 133, 961-976, 2005.

Schumacher, R. S. and Johnson, R. H.: Characteristics of U.S. extreme rain events during 1999-2003, Weather Forecast., 21, 69$85,2006$.

Schumacher, R. S. and Johnson, R. H.: Quasi-stationary, extremerain-producing convective systems associated with midlevel cyclonic circulations, Weather Forecast., 24, 555-574, 2009.

Sénési, S., Bougeault, P., Chèze, J.-L., Cosentino, P., and Thepenier, R.-M.: The Vaison-La-Romaine flash flood: Mesoscale analysis and predictability issues, Weather Forecast., 11, 417-442, 1996.

Stevenson, S. N. and Schumacher, R. S.: A 10-year survey of extreme rainfall events in the central and eastern United States using gridded multisensor precipitation analyses, Mon. Weather Rev., 142, 3147-3162, 2014.

Tryhorn, L., Lynch, A., Abramson, R., and Parkyn, K.: On the meteorological mechanisms driving postfire flash floods: A case study, Mon. Weather Rev., 136, 1778-1791, 2008.

Tsuboki, K. and Sakakibara, A.: Numerical Prediction of HighImpact Weather Systems: The Textbook for the Seventeenth IHP Training Course in 2007, Hydrospheric Atmospheric Research Center, Nagoya University, and UNESCO, Nagoya, Japan, ISBN: 978-4-9980619-8-4, 273 pp., 2007.

Waliser, D. E. and Moncrieff, M.: Year of tropical convection A Joint WCRP-THORPEX activity to address the challenge of tropical convection. GEWEX News, No. 2, International GEWEX Project Office, Silver Spring, MD, 8-9, 2007.

Wang, C.-C.: On the calculation and correction of equitable threat score for model quantitative precipitation forecasts for small verification areas: The example of Taiwan, Weather Forecast., 29, 788-798, 2014.

Wang, C.-C.: The more rain, the better the model performs - The dependency of quantitative precipitation forecast skill on rainfall amount for typhoons in Taiwan, Mon. Weather Rev., 143, 17231748, 2015.

Wang, C.-C., Chen, G. T.-J., Chen, T.-C., and Tsuboki, K.: A numerical study on the effects of Taiwan topography on a convective line during the mei-yu season, Mon. Weather Rev., 133, 32173242, 2005.

Wang, C.-C., Chen, G. T.-J., Yang, S.-C., and Tsuboki, K.: Wintertime supercell thunderstorms in a subtropical environment: $\mathrm{Nu}-$ merical simulation, Mon. Weather Rev., 137, 2175-2202, 2009.

Wang, C.-C., Kuo, H.-C., Chen, Y.-H., Huang, H.-L., Chung, C.-H., and Tsuboki, K.: Effects of asymmetric latent heating on typhoon movement crossing Taiwan: The case of Morakot (2009) with extreme rainfall, J. Atmos. Sci., 69, 3172-3196, 2012.

Wang, C.-C., Chen, Y.-H., Kuo, H.-C., and Huang, S.-Y.: Sensitivity of typhoon track to asymmetric latent heating/rainfall induced by Taiwan topography: A numerical study of Typhoon Fanapi (2010), J. Geophys. Res.-Atmos., 118, 3292-3308, doi:10.1002/jgrd.50351, 2013a. 
Wang, C.-C., Kuo, H.-C., Yeh, T.-C., Chung, C.-H., Chen, Y.-H., Huang, S.-Y., Wang, Y.-W., and Liu, C.-H.: Highresolution quantitative precipitation forecasts and simulations by the Cloud-Resolving Storm Simulator (CReSS) for Typhoon Morakot (2009), J. Hydrol., 506, 26-41, doi:10.1016/j.jhydrol.2013.02.018, 2013b.

Wang, C.-C., Hsu, J. C.-S., Chen, G. T.-J., and Lee, D.-I.: A study of two propagating heavy-rainfall episodes near Taiwan during SoWMEX/TiMREX IOP-8 in June 2008. Part I: Synoptic evolution, episode propagation, and model control simulation, Mon. Weather Rev., 142, 2619-2643, 2014.

Wei, C.-H., Chuang, Y.-C., Hor, T.-H., Liao, C.-C., and Yeh, N.-C.: Dual-Doppler radar investigation of a convective rainband during the impact of the southwesterly monsoonal flow on the circulation of Typhoon Morakot (2009), J. Meteorol. Soc. Jpn., 92, 363-383, 2014.

Weisman, M. L. and Klemp, J. B.: Characteristics of isolated convective storms, in: Mesoscale Meteorology and Forecasting, edited by: Ray, P. S., Amer. Meteor. Soc., Boston, MA, USA, 331-358, 1986.
Willoughby, H. E., Marks Jr., F. D., and Feinberg, R. J.: Stationary and moving convective bands in hurricanes, J. Atmos. Sci., 41, 3189-3211, 1984.

Wu, L., Liang, J., and Wu, C.-C.: Monsoonal influence on Typhoon Morakot (2009). Part I: Observational analysis, J. Atmos. Sci., 68, 2208-2221, 2011.

Yang, S., Kang, K.-R., Cui, X., and Wang, H.: Diagnostic analysis of the asymmetric structure of the simulated landfalling typhoon "Haitang", Prog. Nat. Sci., 18, 1249-1260, 2008.

Ying, Y. and Zhang, Q.: A modeling study on tropical cyclone structural changes in response to ambient moisture variations, J. Meteorol. Soc. Jpn., 90, 755-770, 2012.

Yu, C.-K. and Chen, Y.: Surface fluctuations associated with tropical cyclone rainbands observed near Taiwan during 2000-08, J. Atmos. Sci., 68, 1568-1585, 2011.

Yu, C.-K. and Cheng, L.-W.: Distribution and mechanisms of orographic precipitation associated with Typhoon Morakot (2009), J. Atmos. Sci., 70, 2894-2915, doi:10.1175/JAS-D-12-0340.1, 2013. 